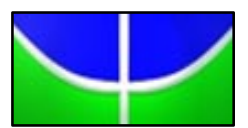

UNIVERSIDADE DE BRASÍLIA

Centro de Excelência em Turismo

Pós-graduação Lato Sensu

Curso de Especialização em Formação de Professores e Pesquisadores em

Turismo e Hospitalidade
\end{abstract}

\title{
TURISMO E UFOLOGIA: \\ UFO TURISMO
}

Ana Rita Sabbag Amaral Batista

Deis Elucy Siqueira

Monografia apresentada ao Centro de Excelência em Turismo da Universidade de Brasília como requisito parcial para a obtenção do certificado de Especialista em Formação de Professores e Pesquisadores em Turismo e Hospitalidade.

Brasília-DF, fevereiro de 2006. 


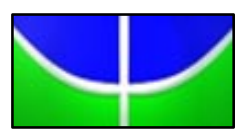

UNIVERSIDADE DE BRASÍLIA

Centro de Excelência em Turismo

Pós-graduação Lato Sensu

Curso de Especialização em Formação de Professores e Pesquisadores em

Turismo e Hospitalidade
\end{abstract}

\title{
TURISMO E UFOLOGIA: \\ UFO TURISMO
}

Ana Rita Sabbag Amaral Batista

Deis Elucy Siqueira

Monografia apresentada ao Centro de Excelência em Turismo da Universidade de Brasília como requisito parcial para a obtenção do certificado de Especialista em Formação de Professores e Pesquisadores em Turismo e Hospitalidade.

Brasília-DF, fevereiro de 2006. 
UNIVERSIDADE DE BRASÍLIA

Centro de Excelência em Turismo

Pós-graduação Lato Sensu

Curso de Especialização em Formação de Professores e Pesquisadores em

Turismo e Hospitalidade

Monografia apresentada ao Centro de Excelência em Turismo da Universidade de Brasília como requisito parcial para a obtenção do certificado de Especialista em Formação de Professores e Pesquisadores em Turismo e Hospitalidade.

\section{Ana Rita Sabbag Amaral Batista}

\section{Aprovado por:}

Professora Orientadora

Professor(a)

Brasília, DF, fevereiro de 2006. 
Dedico este trabalho a todos que me ajudaram direta e indiretamente para a conclusão deste. 


\section{Agradecimentos:}

Aos meus pais e irmãos que me apoiaram em todas as fases de minha pesquisa.

Ao Leandro Queiroz Soares, por todo amor, paciência e conhecimento transmitido.

A doutora e orientadora Deis Siqueira, que me acolheu de braços abertos, mesmo com uma temática delicada e desafiadora.

$\mathrm{E}$ a todos que me ajudaram de alguma forma com a conclusão desta monografia. 


\section{Resumo}

O presente trabalho teve como finalidade identificar se o turismo está se apropriando do conhecimento oriundo da ufologia, na tentativa de criar um novo segmento turístico. Dentre os principais elementos que serviram como embasamento teórico, destacam-se: os conceitos de turismo e ufologia; a história da ufologia, bem como seus vieses e parâmetros (mundiais e nacionais); e dados das cidades que se utilizam ou que tenham potencial para explorar o turismo com aspectos ufológicos. Em sua dimensão metodológica, ressalta-se que a pesquisa utilizou-se de pesquisa bibliográfica, e, sobretudo, utilizou-se no corpo do trabalho de figuras que visaram auxiliar o entendimento do leitor, já que a temática é, ainda, pouco explorada no meio acadêmico. 


\section{Sumário}

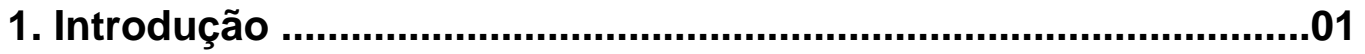

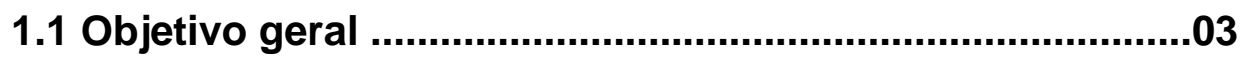

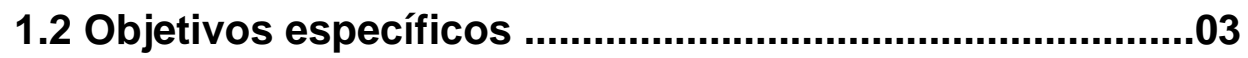

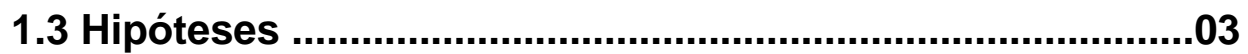

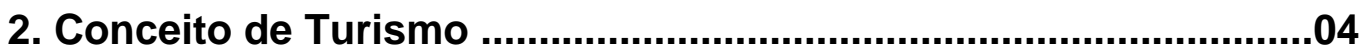

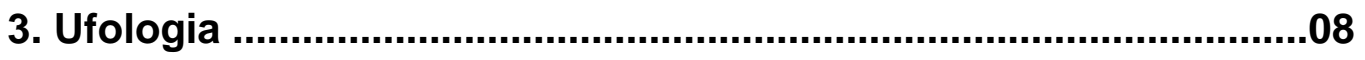

3.1 Revisão Bibliográfica ................................................08

3.2 Histórico .....................................................................11

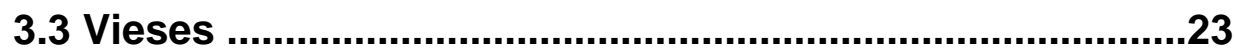

3.3.1 Científico ..............................................................23

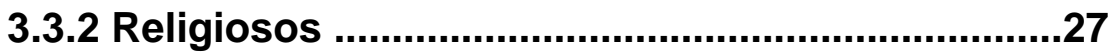

3.4 Parâmetro da Ufologia Mundial e Nacional ......................29

3.4.1 Parâmetro Mundial ...............................................29

3.4.2 Parâmetro Nacional ..............................................32

3.4.3 Casos Ufológicos ..............................................35

3.4.3.1 Roswell ...................................................35

3.4.3.2 Varginha - MG ....................................36

3.4.3.3 Barney e Betty Hil ..........................38

3.4.3.4 Ilha de Trindade- ES ..............................39

3.4.3.5 A Noite Oficial dos Óvnis - Brasil ...........40

4. Ufo turismo ......................................................................................41

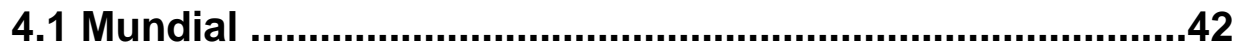

4.1.1 Roswell ..............................................................42

4.1.2 Círculos Ingleses .............................................47

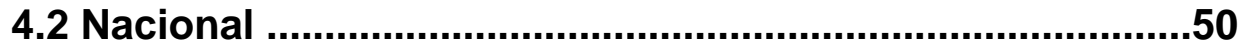

4.2.1 Região Centro Oeste ...........................................50 
4.2.1.1 Parque Chapada dos Guimarães - MT ...50

4.2.1.2 Serra do Roncador - MT 51

4.2.1.3 Alto Paraíso - Go .55

4.2.2 Região Nordeste .56

4.2.2.1 Chapada Diamantina - BA .....................56

4.2.2.2 Parque Serra da Capivara - PI ................57

4.2.2.3 Município de Ingá - PB ...........................58

4.2.3 Região Norte ...................................................60

4.2.3.1 Cidade de Alenquer - PA ........................62

4.2.3.2 Cidade de Monte Alegre - PA .................62

4.2.3.3 Ilha de Marajó - PA ..................................63

4.2.3.4 São Gabriel da Cachoeira - AM ..............63

4.2.4 Região Sul .....................................................65

4.2.4.1 Itaara - RS .........................................65

4.2.4.2 Município de Garuva - SC ......................65

4.2.5 Região Sudeste .............................................66

4.2.5.1 Varginha - MG ......................................66

4.2.5.2 São Thomé das Letras - MG ...................68

4.2.5.3 Peruíbe - SP .......................................69

4.2.5.4 Conservatória - RJ .................................70

4.2.5.5 Outras Regiões .......................................71

5. Considerações Finais ....................................................................72

Referências Bibliográficas ...........................................................73 


\section{Introdução}

A ufologia, denominada por diversos especialistas no assunto como o estudo ou a pesquisa sobre um fenômeno conhecido como "objeto voador não identificado", é um recurso forte como gerador de renda. Todos os anos são gerados milhares de empregos com a realização de congressos, palestras, e venda de livros acerca de assuntos ufológicos.

Uma vez que o turismo pode ser considerado como um fenômeno capitalista, vê-se uma necessidade de estudo acerca de como o turismo se apropria de outros segmentos, tal como a ufologia, como forma de ampliar e oferecer novos tipos de atrativos aos seus consumidores.

Observando os vários segmentos turísticos, diagnosticou-se um novo tipo: o ufo turismo ou turismo ufológico. Este novo segmento não é alarmantemente divulgado pela mídia, e não possui, ainda, uma definição acadêmica. Sabe-se que há um movimento que explora o potencial de regiões que supostamente apresentam uma grande incidência de avistamentos dos denominados óvnis. Tais regiões atraem pessoas interessadas em vida extraterrestre, misticismo, astronomia, ficção científica, dentre outros assuntos correlatos.

A necessidade de um estudo científico abordando a ufologia configura-se, então, relevante ao estudo turístico, uma vez que há somente materiais de caráter não científico relacionado ao tema.

Que fique claro, desde já, que não é objetivo desta monografia provar a existência de óvnis, extraterrestres e elementos afins, mas sim estudar o surgimento de um novo tipo de turismo, bem como de identificar e pesquisar as regiões que já exploram o turismo ufológico.

O presente trabalho inicia-se com a exposição dos principais conceitos de turismo e turistas, bem como delineia os principais segmentos que hoje compõem as suas demandas, além de reflexões sobre a correlação de turismo e ufologia.

Em um segundo momento, a ufologia será a variável particularmente estudada. Para situar o leitor acerca desta temática ainda pouco conhecida no meio acadêmico, abordaremos as conceituações existentes acerca da ufologia e 
tal como a pessoa que a estuda, denominada de ufólogo, bem como as subdivisões decorrentes da mesma.

Em seguida, passaremos a dissertar sobre a história da ufologia, passando desde a era pré-histórica, idade média, renascimento, até os dias de hoje. Adiante, abordaremos os vieses existentes na ufologia, sendo que estes podem ser de caráter científico ou religioso.

Em um terceiro momento, veremos como a ufologia mundial e nacional é estudada e encarada desde a perspectiva científica. Serão expostos, também, os principais casos de avistamentos de supostas naves e visitas de extraterrestre em nosso planeta.

Por fim, proporemos uma definição do que é ufo turismo. Além de diagnosticar as principais cidades mundiais e, principalmente as nacionais que utilizam ou que tenham potencial para explorar ou trabalhar com o turismo ufológico.

Uma vez considerada a relevância do sugerido tema, o presente trabalho propõe-se a responder a seguinte questão: o turismo como fonte de geração de renda e representante de manifestações culturais e históricas, está se "apropriando" do conhecimento oriundo da ufologia na tentativa de criar um novo segmento turístico?

A resposta a essa pergunta foi buscada mediante a realização de uma pesquisa bibliográfica, que incluiu materiais eletrônicos, livros e periódicos, tendo como foco os objetos de estudo 'ufologia' e 'turismo', bem como a relação existente entre ambos.

Vale salientar, ainda, que se optou deliberadamente por apresentar as figuras no corpo do trabalho, e não como anexos, em vista de facilitar a compreensão dos elementos ufológicos, já que se trata de um fenômeno pouco conhecido. Além de acrescentar informações adicionais e ilustrar o texto, elas também contribuem expressamente para o entendimento do leitor acerca do movimento ufológico. 


\subsection{Objetivo Geral}

Identificar se o turismo está se "apropriando" da ufologia.

\subsection{Objetivos Específicos}

- Identificar como a ufologia pode se agregar ao turismo na criação de novos segmentos.

- Demonstrar como o turismo ufológico pode se constituir um nicho de mercado.

- Explicitar as correlações entre turismo e ufologia.

\subsection{Hipóteses}

- Uma vez que a ufologia, da perspectiva de alguns empreendedores turísticos, representa um grande mercado a ser explorado, hipotetiza-se que o turismo está oportunamente se "apropriando" da mesma.

- A ufologia pode se agregar ao turismo na criação de novos segmentos por intermédio da própria demanda, da mídia e do trade turístico que explora, ao máximo, novos atrativos aos seus consumidores.

- O turismo ufológico está se constituindo um nicho de mercado uma vez que há um crescente aumento da demanda, e conseqüentemente, uma forte exploração e divulgação turística estimulada pela mídia e o trade turístico.

- As correlações existentes entre turismo e ufologia são mercadológicas, uma vez que o turismo é um produto capitalista e, como tal, visa novos atrativos para seus consumidores. 


\section{Conceito de Turismo}

Uns dos primeiros autores a conceituar o turismo foi o economista austríaco Hermann Von Schullern Zu Schattenhofen com seu livro "turismo e economia nacional". Remonta-se que foi em 1911, época que os estudos científicos acerca do turismo começaram a se desenvolver. Segue abaixo a referida definição:

"Turismo é a soma das operações, principalmente de natureza econômica, que estão diretamente relacionadas com a entrada, permanência e o deslocamento de estrangeiros para dentro e para fora de um país, cidade ou região" (Wahab apud Dias, 2002: 23).

A partir desta data os inúmeros conceitos de turismo e turistas foram surgindo, virando suas conceituações ambíguas e controversas. No decorrer do século $X X$, vemos que em sua maioria as conceituações existentes privilegiam o aspecto econômico (Siqueira, 2005). A guisa de exemplo, cita-se a definição proposta por Arrilaga apud Barreto (1995):

"Turismo é o conjunto de deslocamentos voluntários e temporais determinados por causa alheia ao lucro; conjunto de bens, serviços e organização que determinam e tornam possíveis estes deslocamentos e as relações e fatos que entre aqueles e os viajantes têm lugar" (p. 12).

Atualmente, uma das definições mais aceita pelo ponto de vista formal e consensual é o da Organização Mundial do Turismo - OMT: “(..) como o deslocamento para fora do local de residência por um período superior a sessenta dias motivado por razões não econômicas" (Ignarra, 2001: 23). A OMT diferencia, ainda, turista (pessoa que viaja por um objetivo de recreação), visitante (visitantes que permanecem no lugar visitado pelo menos por uma noite) e excursionistas (visitantes que não pernoitam no local de visita).

Já a Organização das Nações Unidas - ONU, propõe a seguinte definição de turista:

"Toda pessoa, sem distinção de raça, sexo, língua e religião, que ingresse no território de uma localidade diversa daquela em que tem residência habitual e nele permaneça pelo prazo mínimo de 24 horas e 
máximo de 6 meses, no transcorrer de um período de 12 meses, com finalidade de turismo, recreio, esporte, saúde, motivos familiares, estudos, peregrinações religiosas ou negócios, mas sem propósitos de imigração" (Ignarra, 2001: 25).

Enfim, nos deparamos com diversos conceitos de turismo visto por diferentes aspectos (como o da ONU que enfatiza uma perspectiva recreacional, sem propósito de imigração), e, sobretudo como o da OMT com uma centralidade no âmbito econômico (Siqueira, 2005:81).

Segundo Barreto (1995) entre as definições correntes, alguns elementos são priorizados: a espontaneidade e a procura do prazer por parte do turista, o caráter não lucrativo da visita e o tempo de permanência do visitante.

Em relação aos turistas, (Barreto, 1995:26) classifica-os como:

- Alocêntricos - turistas aventureiros que vão à procura de locais novos e não explorados ainda pelo turismo.

- Messocêntricos - turistas que viajam individualmente, mas para lugares já explorados pelo turismo, sendo sua relação com a população local mais comercial.

- Psicocêntrico - turistas que vão aos lugares já explorados, utilizando-se de pacotes, deixando-se levar pela influência social.

Há, ainda, diferentes formas de se fazer turismo. Tais modalidades turísticas são classificadas por Barreto (1995) e Dias (2002) da seguinte forma:

- Emissivo;

- Receptivo;

- Nacional;

- Internacional;

- Exportação;

- Importação; 
- Minorias ou seletivo;

- Massas;

- Classes privilegiadas;

- Classes médias;

- Classes populares;

- Definido;

- Livre;

- Hoteleiro;

- Extra hoteleiro.

Há, também, uma vasta segmentação turística. Segue abaixo alguns tipos de segmentação, descritos por Ignarra (2001) com o intuito de ilustrar a grande diversidade motivacional das viagens.

\section{Tabela 1: Segmentações Turísticas}

\begin{tabular}{|c|c|}
\hline Critério de segmentação & Segmentos \\
\hline \multirow{4}{*}{ Idade } & Turismo Infantil \\
\hline & Turismo juvenil \\
\hline & Turismo de meia idade \\
\hline & Turismo de $3 a$ idade \\
\hline \multirow{3}{*}{ Nível de Renda } & Turismo Popular \\
\hline & Turismo de Classe Média \\
\hline & Turismo de Luxo \\
\hline \multirow[t]{5}{*}{ Meio de Transporte } & Turismo Aéreo \\
\hline & Turismo Rodoviário \\
\hline & Turismo Ferroviário \\
\hline & Turismo Marítimo \\
\hline & Turismo Fluvial/Lacustre \\
\hline \multirow{3}{*}{ Duração da Permanência } & Turismo de Curta Duração \\
\hline & Turismo de Média Duração \\
\hline & Turismo de Longa Duração \\
\hline
\end{tabular}




\begin{tabular}{|c|c|}
\hline \multirow{5}{*}{ Distância do Mercado Consumidor } & Turismo Local \\
\hline & Turismo Regional \\
\hline & Turismo Nacional \\
\hline & Turismo Continental \\
\hline & Turismo Intercontinental \\
\hline \multirow{3}{*}{ Tipo de Grupo } & Turismo Individual \\
\hline & Turismo de Casais \\
\hline & Turismo de Famílias \\
\hline \multirow{2}{*}{ Sentido do Fluxo Turístico } & Turismo Emissivo \\
\hline & Turismo Receptivo \\
\hline \multirow{4}{*}{$\begin{array}{l}\text { Condição Geográfica da } \\
\text { Destinação Turística }\end{array}$} & Turismo de Montanha \\
\hline & Turismo de Praia \\
\hline & Turismo de Neve \\
\hline & Turismo de Campo \\
\hline \multirow{3}{*}{ Aspecto Cultural } & Turismo Étnico \\
\hline & Turismo Religioso \\
\hline & Turismo Histórico \\
\hline \multirow{4}{*}{$\begin{array}{l}\text { Grau de Urbanização da } \\
\text { Destinação Turística }\end{array}$} & Turismo de Grandes Metrópoles \\
\hline & Turismo de pequenas Cidades \\
\hline & Turismo Rural \\
\hline & Turismo de Áreas Naturais \\
\hline \multirow{8}{*}{ Motivação da Viagem } & Turismo de Negócios \\
\hline & Turismo de Eventos \\
\hline & Turismo de Lazer \\
\hline & Turismo de Saúde \\
\hline & Turismo Educacional \\
\hline & Turismo de Aventuras \\
\hline & Turismo Esportivo \\
\hline & Turismo de Pesca \\
\hline
\end{tabular}

Segundo Ignarra (2001), estes segmentos não esgotam as possibilidades de tipos de turismo. Aí entra mais um novo tipo de segmentação engatinhando timidamente: o Ufo Turismo ou o Turismo Ufológico.

Considerando que o estudo do turismo é multi, pluri, inter e transdiciplinar, já que ocorre em distintos campos de estudo (Siqueira, 2005), Beni (2001) 
sustenta que "(...) a conceituação deste não pode ficar limitada a uma simples definição, e muito menos dizer que certo conceito é errôneo ou inadequado" (p. 39), mesmo sabendo das várias perspectivas que circundam estes conceitos acerca do turismo. É preciso reflexão e informação acerca dos parâmetros que cada teoria predispõe a contribuir para uma unificação dos conceitos.

Por fim, a intercessão entre as variáveis ufologia e turismo, tema desta monografia, se dá forma privilegiada, pois além de ambas possuírem este aspecto multi, pluri, inter e transdiciplinar, elas também estão em busca de alternativas frente à crise de paradigma mecanicista e fragmentado do nosso atual sistema (Siqueira, 2005).

\section{Ufologia}

\subsection{Revisão bibliográfica}

Neste capítulo será apresentado o produto de uma revisão de literatura acerca do objeto 'ufologia'. O insumo para a construção deste material foi obtido através de livros, periódicos e mídia eletrônica.

Como suporte teórico para o presente trabalho se recorreu, inicialmente, à literatura acerca de duas variáveis: a ufologia e o turismo. Em um segundo momento, buscou-se na literatura existente, uma correlação entre ambas variáveis.

A palavra ovniologia (de óvni + o + log (o) ia) ou ufologia significa "ciência, estudo ou tratado acerca dos óvnis" (Ferreira, 1986: 1241; Michaelis, 1998: 2148).

Ufologia ou ovniologia segundo o site Era da Paz (2004) "é a palavra que utilizamos para definir a pesquisa e coleta de dados sobre um fenômeno conhecido como objeto voador não identificado (óvni, em português ou ufo unidentified flying object)".

Já em Socex (2005) definem a ufologia como:

"O estudo, a pesquisa e a análise do aparecimento de objetos, máquinas ou luzes, no céu, na terra, e nas águas, seus movimentos, reações, formas e efeitos produzidos, de origem não terráquea ou sem um fator ou processo físico, químico ou psicológico conhecidos, bem como é o estudo e a análise do 
comportamento e das formas de atuação sobres os Seres deste planeta, por parte dos Seres ou Inteligências que dirigem ou mantém sob controle, aqueles objetos, máquinas ou luzes".

A ufologia pode se subdividida em três grandes segmentos: ufologia científica, ufologia mística/esotérica e ufologia holística. Abaixo segue algumas das principais características de cada um deles:

Ufologia Científica: é o ramo da pesquisa ufológica que se atém apenas àquilo que pode ser analisado e mensurado pelas metodologias já aceitas pela ciência acadêmica, seguindo exclusivamente a ciência racional e experimental. A ufologia científica pesquisa a partir do pressuposto de que os ufos são um fenômeno mensurável e, portanto, com existência física objetiva. Analisa fotos e filmes de supostos ufos. Testemunhas e possíveis marcas deixadas pelas naves no solo são as principais fontes de pesquisa.

Ufologia Mística/Esotérica: possui uma visão espiritualizada do fenômeno ufo. Além desta visão, divulga a ufologia em outros aspectos: místico, esotérico e filosófico. Procura mostrar que apenas com uma revisão dos atuais dogmas científicos, religiosos e filosóficos poderemos entender o fenômeno e, no futuro, nos integrar com seres de outros planetas. Segundo sua linha de estudo, suas fontes de pesquisa são as mensagens telepáticas e psicografadas de Seres Extraterrestres, clarividência, viagens astrais, intuição, e o exercício pleno das faculdades Parapsicológicas.

Ufologia Holística: a ufologia holística procura unir as duas correntes acima mencionadas. Somando a pesquisa científica aos preceitos da ufologia esotérica/mística, prega que somente uma visão ampla e sem preconceitos poderá ajudar a entender o fenômeno ufo.

Existe, portanto, no campo ufológico uma grande desarmonia entre as correntes. A científica preocupa-se com o fenômeno em si, não dando a devida importância ao aspecto espiritual. Sob outra ótica temos os excessivamente místicos beirando ao fanatismo, estabelecendo muitas vezes, um cunho negativo e sensacionalista ao fenômeno atingindo a mídia.

As pessoas que estudam a ufologia são denominadas ufólogos. Segundo Socex (2005) ufólogo 
“(...) é a pessoa que estuda, pesquisa, analisa e divulga a respeito das naves extraterrestres e de seus tripulantes incluindo os movimentos, efeitos produzidos, reações, comportamentos, tecnologia formas de comunicação, aparições, e com isso, levanta hipóteses e teorias quanto ao fenômeno ufológico". como:

Conforme (Ufogênesis, 1996), os ufólogos podem ser distinguidos

- Auxiliar de Ufólogo - é o principiante em ufologia;

- Ufólogo Científico - é o ufólogo que segue a linha científica, procurando desmistificar eventos explicáveis;

- Ufólogo Paraolístico - é o ufólogo que estuda e divulga a ufologia denominada mística e esotérica. Este tipo de ufólogo é considerado médium, pois possui características como a supostas viagens astrais e possíveis contatos com Seres Extraterrestres (por meio de mensagens telepáticas e psicografradas);

- Ufólogo Holístico - Analisa os casos ufológicos sob todos os pontos de vista. Segue a linha holística no qual além de seguir a corrente científica, usa de suas faculdades intuitivas e /ou psicopoderes como complemento para o estudo;

- Ufólogo Independente - é o ufólogo que estuda, analisa, pesquisa e divulga casos ufológicos, sem estar filiado ou mesmo sem estar cadastrado em instituição ufológica;

- Ufólogo de Gabinete - compila assuntos ufológicos exclusivamente por televisão, jornais, revistas e Web. Sua principal característica é fato de nunca sair de sua casa para investigar eventos ufológicos.

Existe, também, a denominação anti-ufólogos: trata-se de cientistas ortodoxos, no qual utilizam ferramentas disponíveis para explicar as aparições como sendo exclusivamente fenômenos naturais, erros de interpretação ou fraude.

Pelo ângulo da ciência, os relatos dos supostos incidentes estão longe de serem conclusivos. Conforme Russo (1985) 
“(...) as grandes cidades são evitadas efetivamente pelos óvnis, talvez pelo simples fato de possuirmos nos grandes centros meios eficazes de comunicação, proteção militar, além da interferência de testemunhas que as grandes metrópoles proporcionam" (p. 100).

Além disto, os óvnis já foram supostamente rastreados a velocidades absurdas e suas características relevantes são a capacidade de aceleração e desaceleração imediatas, além das estonteantes manobras que desafiam todas as leis conhecidas da física.

A rica literatura encontrada, relata que esses óvnis quase sempre são de coloração prateada e emitem variantes de luminosidade que abrangem várias cores. Estas máquinas provocariam radiações de calor que literalmente crestam a vegetação circunvizinha aos avistamentos.

Por conseguinte, a não resolução científica destes avistamentos é uma característica comum para a ufologia, dentre os inúmeros relatos de objetos misteriosos a riscar o céu não só brasileiro, mas em todo o nosso planeta.

\subsection{Histórico}

Segundo o site Era da Paz (2004) a história da ufologia moderna possui uma data inicial: 24 de junho de 1947. O americano Kenneth Arnold era piloto de pequenos aviões e fazia serviços de encomenda. Homem respeitado, casado e pai de dois filhos, foi testemunha do que os ufólogos chamam de um contato visual com óvnis, enquanto sobrevoava com seu monomotor as cidades de Chebalis e Jakima, no estado de Washington. Ao sobrevoar o monte Rainer, ele afirma ter avistado nove objetos "em forma de discos" se movendo a grande velocidade, muito mais veloz que a velocidade do som (cerca de $1.200 \mathrm{~km}$ por hora), algo impossível para qualquer avião terráqueo naquela época. Segue abaixo o relato do referido piloto americano:

"Intrigado, olhei para trás e vi nove coisas, parecidas com aeronaves, que avançavam em diagonal, como se fossem uma corrente. Por um momento pensei que poderiam ser um novo tipo de avião a jato, mas em seguida descobri que não tinham cauda. Essas coisas desconhecidas voavam tranqüilas e rapidamente entre os picos da montanha, com uma velocidade fantástica. Deduzi que a corrente deveria 
ter uma extensão de oito quilômetros e que, para cobrir a distância entre o pico do extremo sul do Rainer e o cume oeste do monte Adams, não tinham gasto mais de um minuto e quarenta e dois segundos. Voavam como gansos, mas como gansos mais velozes, nunca vistos, porque calculei que atingiam uma velocidade de 2.700 quilômetros por hora." (Era da paz, 2004)

A partir do relato de Kenneth Arnold (publicado pelos jornais americanos e pesquisado pela aeronáutica americana) surge à palavra ufo (unidentified flying object) e então a denominação de disco voador (uma vez que Arnold supostamente observou tais objetos em formas de flying saucer - em português (pires voador').

A grande maioria dos ufólogos considera o depoimento de Arnold um marco para a ufologia moderna. Os avistamentos anteriores são de grande valia para a ufologia, mas nenhum deles alcançou a repercussão do caso Arnold.

Alguns destes avistamentos foram relatados exatamente na década de 40 , durante a Segunda Guerra Mundial, onde segundo fontes diversas (Ufo, 2004; Era da paz, 2004) os exércitos alemães e americanos teriam encontrado objetos altamente luminosos observando seus aviões, com manobras inconcebíveis para a tecnologia terrestre da época. Estes objetos luminosos foram estereotipados pela expressão foo fighters - (em português - bolas de fogo) (Ufo, 2004). Os foo fighters espalharam o medo tanto entre os alemães (que acreditavam serem armas norte-americanas), quanto entre os norte-americanos (que acusavam serem novos inventos de guerra alemã).

Ao final da guerra, oficiais militares (em ambos os países) não conseguiram comprovar se os foo fighters eram (ou não) efetivamente armas de grande poder tecnológico, tal como comumente hipotetizavam.

A partir dos relatos contemporâneos, pesquisadores no mundo todo começaram a hipotetizar evidências ufológicas em épocas remotas.

Ufólogos trabalham com a hipótese de que seres extraterrestres visitam o nosso planeta desde a época da Pré-História e, para registrarem os fatos ocorrentes em seu cotidiano, os povos pré-históricos pintavam em cavernas representações daquilo que tinham um contato visual ou físico, tais como animais, homens caçando e, até mesmo, como muitos acreditam ufos. 
Os antigos monumentos dos povos pré-colombianos, egípcios, europeus e asiáticos, deixados por civilizações extintas são consideradas, também, por muitos estudiosos referências ufológicas, uma vez que suas construções, e seus ensinamentos em áreas como astronomia, matemática, química e física são ainda um grande mistério para a humanidade (Ufogênesis, 1996).

Esta área de estudo dentro da ufologia que considera a possibilidade de ter havido visitas de extraterrestres na mais remota antiguidade e sua interação com habitantes terrestres é denominada de "Ufoarqueologia" (Ufogênesis, 1996)

Segundo Neto (1984), o autor suíço Erik Von Daniken

“(...) é uns dos mais conhecidos autores que defende a existência de E.T.s inteligentes que, na época da nossa Pré-Historia trouxeram conhecimentos para a Terra provinda de outros planetas. Achados arqueológicos, pinturas rupestres, monumentos antigos (como as pirâmides do Egito), mapas e marcas no solo são, para Daniken, algumas evidências de que a vida extraterrestre existe" (p. 34).

Entre os registros pictóricos, foram descobertos algumas pinturas rupestres nos cinco continentes que muito se assemelham aos supostos ufos. Mais que isso, muitas figuras parecem ser ocupantes de tais ufos interagindo com humanos. Exemplos destes desenhos podem ser encontrados em cavernas da China, Austrália, África e Brasil.

Seguem abaixo algumas figuras rupestres e seus respectivos comentários, sendo todas extraídas do site Gepuc (2000), que, para muitos ufólogos, representam provas consistentes da existência dos óvnis, que supostamente estariam a "visitar" o planeta Terra desde tempos remotos: 


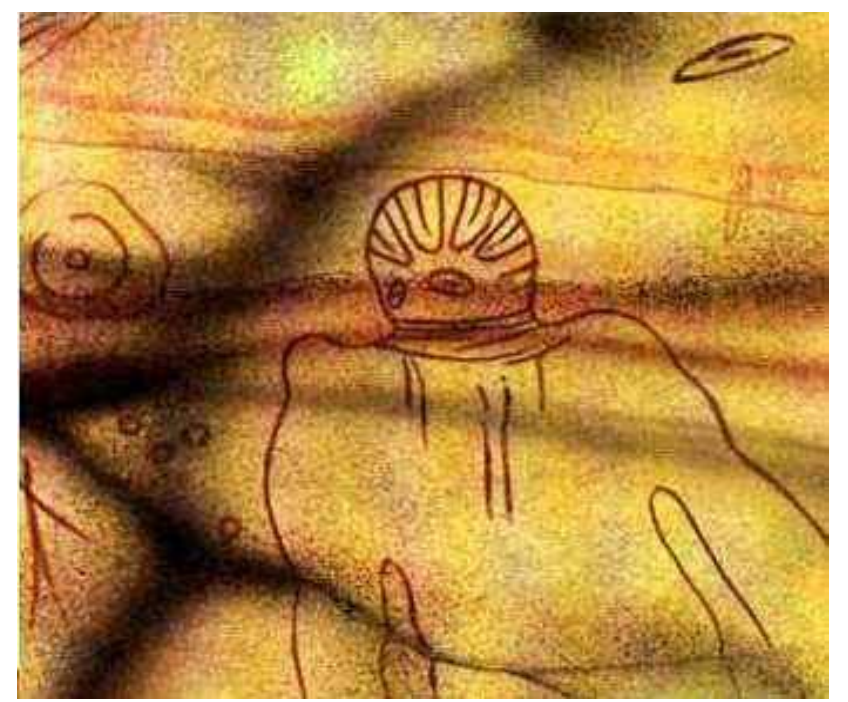

Figura 1 - Desenho encontrado em Tassili, no Saara, Norte da África. Neste desenho, o ser representado apresenta certa semelhança com os homens atuais (capacete, vestuário). Outro "detalhe ufológico" do desenho é o objeto discoidal representado próximo à cabeça da figura representada.

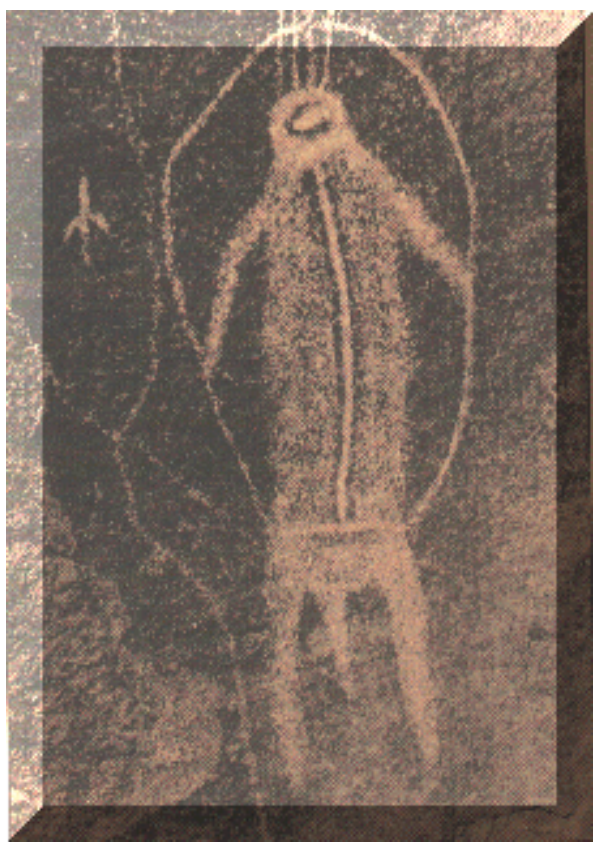

Figura 2 - Pintura de 20 mil anos, investigada pelos irmãos Leyland. É a representação de um ser vestindo roupa com zíper e capacete, saindo de um objeto esférico pousado sobre um tripé. A figura foi descoberta na Austrália. 


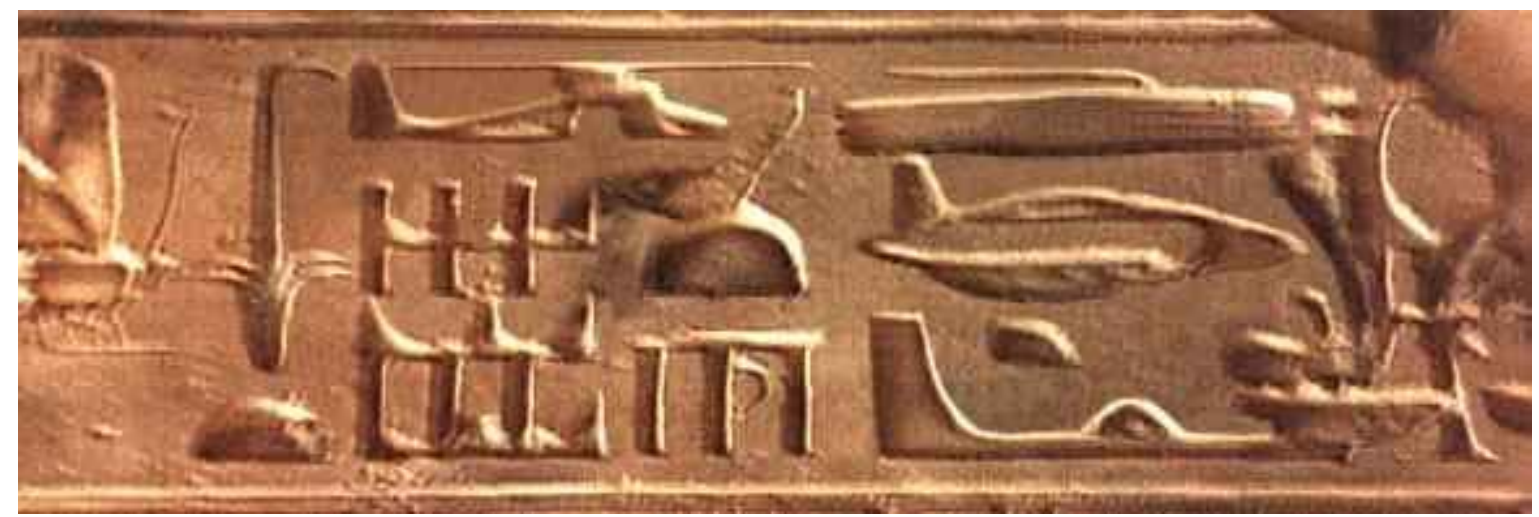

Figura 3 - A fotografia foi obtida em uma câmara mortuária do Templo de Abydos, no Egito. Note que os autores representaram diversos artefatos estranhos à época. Vê-se a representação de um helicóptero, aviões e até o que parece ser um submarino.
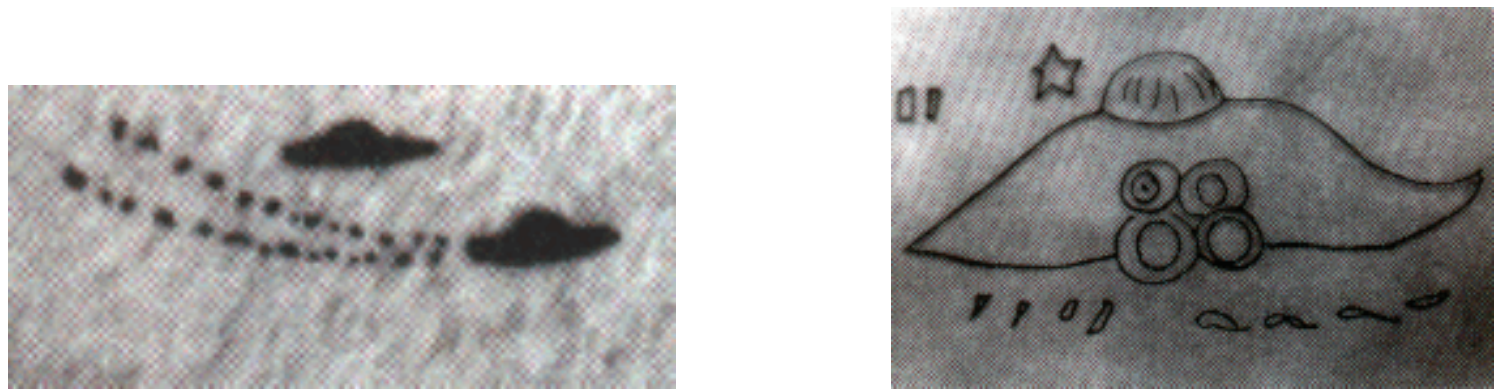

Figuras 4 e 5 - Nas cavernas de Altamira, em Santillana Dei Mar, em Santander, Espanha, foram encontradas pinturas de 20 mil anos de idade, mostrando objetos voadores de formatos lenticulares e até discoidais.

A partir do momento que o homem desenvolveu a escrita, conseqüentemente ficou mais fácil registrar fatos que antes eram narrados por meio da tradição oral ou em desenhos pictóricos. A guisa de exemplo poderia citar a Bíblia judaico-cristã e os antigos textos sagrados da Índia.

A Bíblia, e mais precisamente o Velho Testamento segundo Ufogenesis (1996) possuem inúmeras referências a supostas descidas de naves interplanetárias e ao contato com seus tripulantes. Dentre estas possíveis referências a óvnis destaca-se a do profeta Ezequiel, o qual ocupa uma grande 
parte de seu livro descrevendo em detalhes a forma e a estrutura de um suposto óvni.

Perante os relatos da bíblia, estudiosos primam por uma observação com características ufológicas, uma vez que, dentro das limitações dos conhecimentos de um homem que viveu mais de dois milênios antes do advento das máquinas voadoras atuais, a impossibilidade de expressar qualquer manifesto de algum equipamento tecnológico incompatível com sua época.

"Olhei, e eis que um vento tempestuoso vinha do norte, e uma grande nuvem, com fogo a revolver-se, e resplendor ao redor dela, e no meio disto uma cousa como metal brilhante que saía do meio do fogo" (Ezequiel, 1993: 814).

"Do meio dessa nuvem saía à semelhança de quatro seres viventes, cuja aparência era esta: tinham a semelhança de homem" (Ezequiel, 1993: 814).

"Andando os seres viventes, andavam as rodas ao lado deles; elevando-se eles, também elas se elevavam" (Ezequiel, 1993:814).

"O aspecto das rodas e a sua estrutura eram brilhantes como o berilo; tinham as quatro a mesma aparência, cujo aspecto e estrutura eram como se estivera uma roda dentro da outra" (Ezequiel, 1993:814).

Seguem abaixo, duas figuras que representam a visão descrita de Ezequiel, ambas extraídas do site Gepuc (2000): 

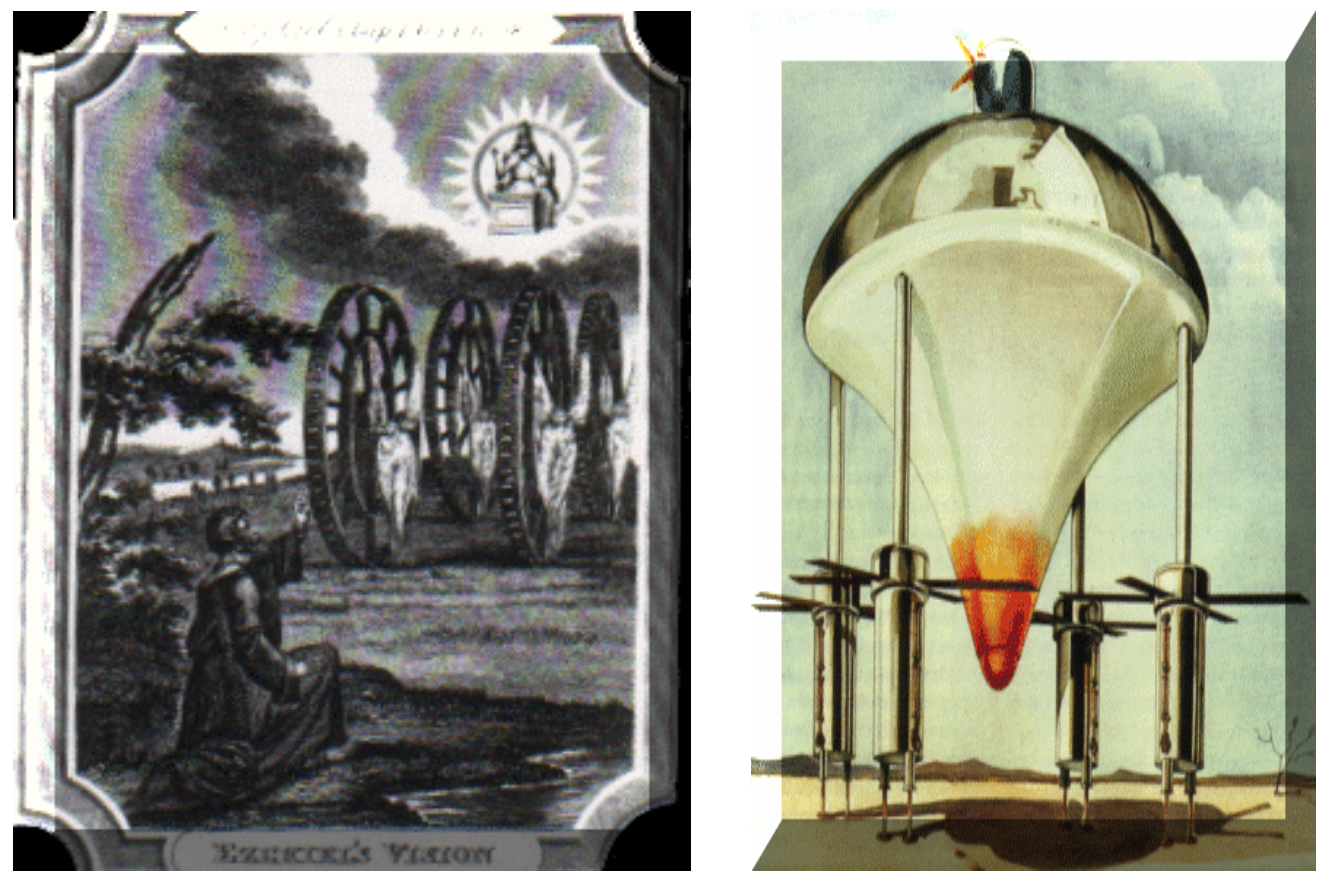

Figuras 6 e 7 - À esquerda a representação do relato de Ezequiel ao pé da letra. À direita a representação da nave Ezequiel segundo o cientista da NASA Joseph Blumrich.

No relato de Moisés conduzindo os israelitas para fora do Egito através do deserto do Sinai até a Terra Prometida está, também, interpretada por muitos ufólogos como uma ocorrência de óvni.

"Então o anjo de Deus, que ia adiante do exercito de Israel, se retirou, e passou para trás deles, também a coluna de nuvem se retirou de diante deles, e se pôs atrás deles" (Êxodo, 1993: 77).

"E ia entre o campo dos egípcios e o campo de Israel; a nuvem era escuridade para aqueles, e para este esclarecia a noite; de maneira que em toda a noite este e aqueles não puderam aproximar-se" (Êxodo, 1993: 77).

Segundo alguns ufólogos, estas colunas de nuvem e luz talvez fossem um óvni - cujo calor, aliás, pode ter dividido as águas do mar vermelho.

Afora estes exemplos, o próprio nascimento de Jesus Cristo, quando uma estrela de características "suspeitas" guiou os reis magos até a manjedoura, pode ser interpretado também, para muitos ufólogos, como referência clara da existência de óvnis em épocas mais antigas (Mistérios do desconhecido, 1992).

Há, ainda, a existência de livros hindus (textos védicos), nos quais existem relatos de naves de deuses - os vimanas, que seriam armas que lembrariam 
nossas modernas armas de destruição em massa, além de supostamente possuírem a capacidade de viajarem a outros mundos (Ufogênesis, 1996).

Deve-se destacar que as visões bíblicas não são aceitas perante toda a corrente ufológica. Alguns ufólogos dão explicações naturais (tais como auroras boreais, ou miragens) para os relatos com cunho ufológico.

Para os que não aceitam relatos bíblicos como referências ufológicas válidas têm, ainda, o recurso dos registros históricos.

Nos tempos dos faraós, antiqüíssimos papiros foram encontrados com relatos de ufos. Segundo (Russo, 1985: 104), este é o caso do Papiro Tulli, que estaria atualmente sob a guarda do museu do Vaticano.

Este documento relataria um hipotético avistamento de um óvni ocorrido durante a $18^{a}$ Dinastia, sob o reinado de TUTMOSES III. Descreve ele que

a respeito de uma singular bola de fogo que viera do céu, algum tempo depois seguida de dezenas de outras que ficaram pairando diante dos olhos atônitos daquele faraó e dos seus exércitos, causando tanta impressão que os escribas receberam ordens de registrar os fatos nos anais reais. (Russo, 1985:104).

No período que se estende do fim da Idade Média até o começo do século $X X$, ficaram registradas em quadros e estampas algumas observações de estranhos objetos no céu, e de grupos de cidadãos espantados assistindo as suas passagens (Gepuc, 2000). Seguem abaixo alguns exemplos extraídos do site Gepuc (2000): 


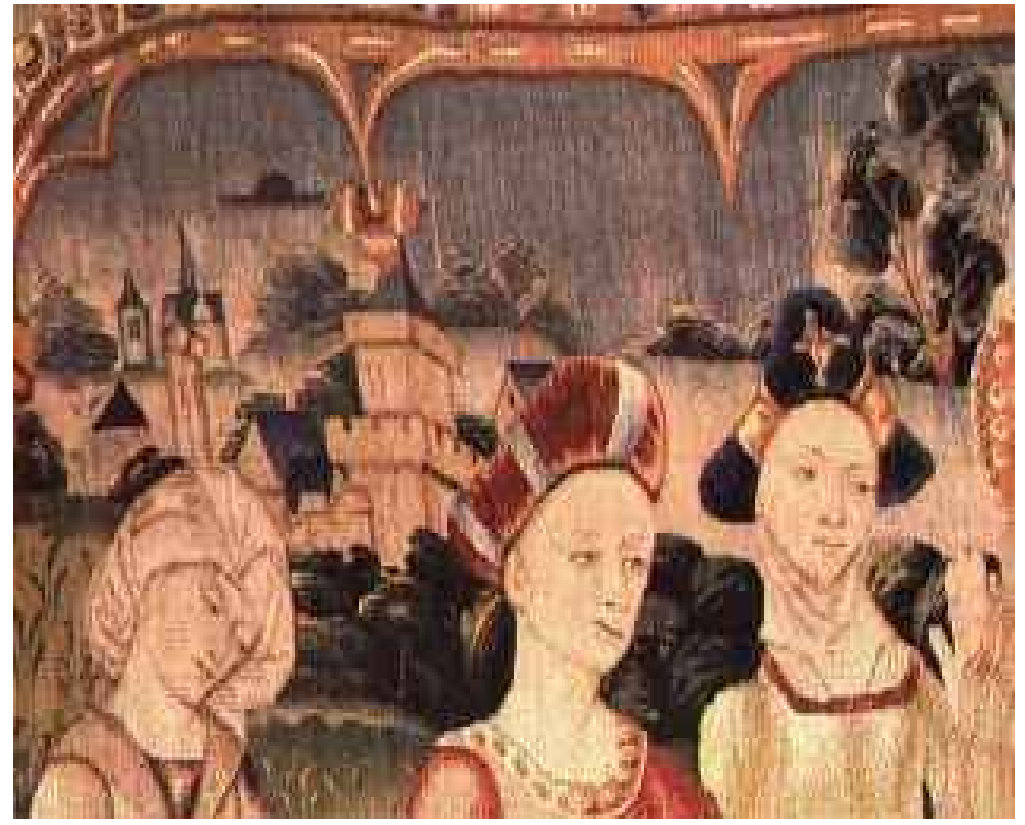

Figura 8 - Tapeçarias do século XIV - Esta tapeçaria do século XIV retrata a vida de Maria. Nota-se que no fundo da imagem existe um objeto suspenso no céu. Este objeto é idêntico a supostos óvnis atuais. Esta tapeçaria encontra-se na Basílica Francesa Notre Dame de Beaune, em Burgandy, França.

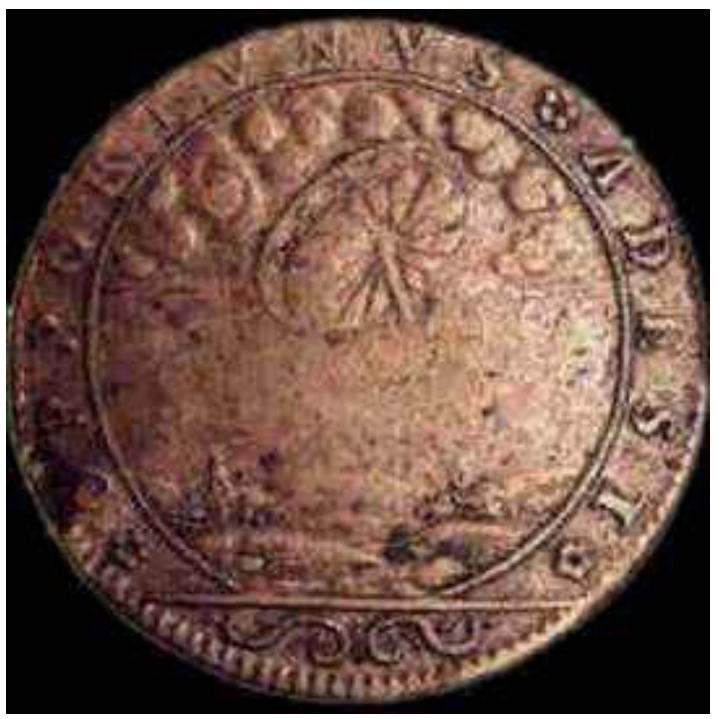

Figura 9 - Medalha Francesa, produzida por volta de 1680 para comemorar um fenômeno celeste visto por muitas pessoas da época. Note o objeto discoidal próximo às nuvens. 


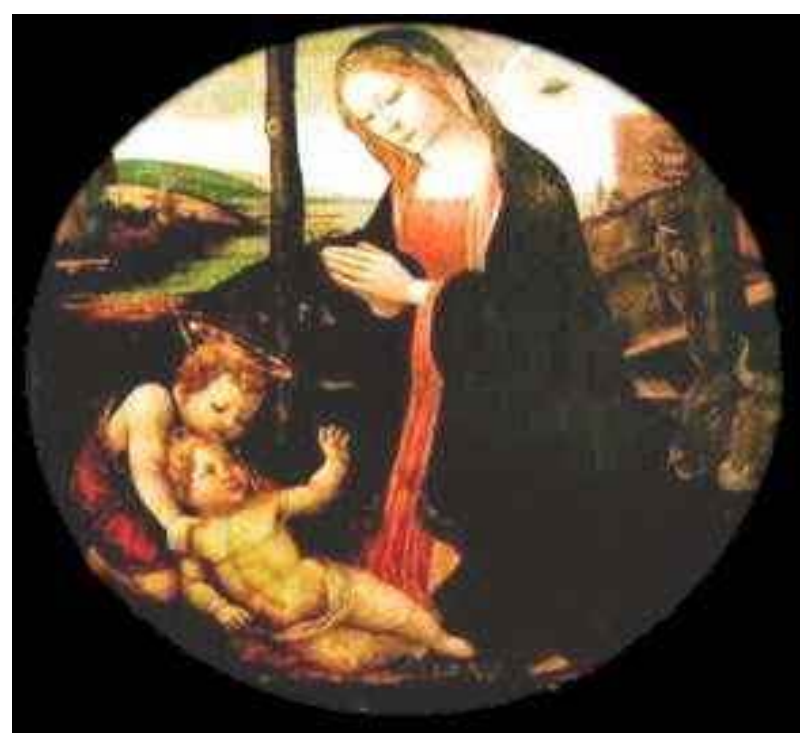

Figura 10 - Madonna e o Menino (séc. XV) - Esta pintura encontra-se no Palazzo Vecchio, em Florença, Itália. A autoria deste quadro é atribuída a Fillippo Lippi. Note o estranho objeto acima do ombro de Nossa Senhora.

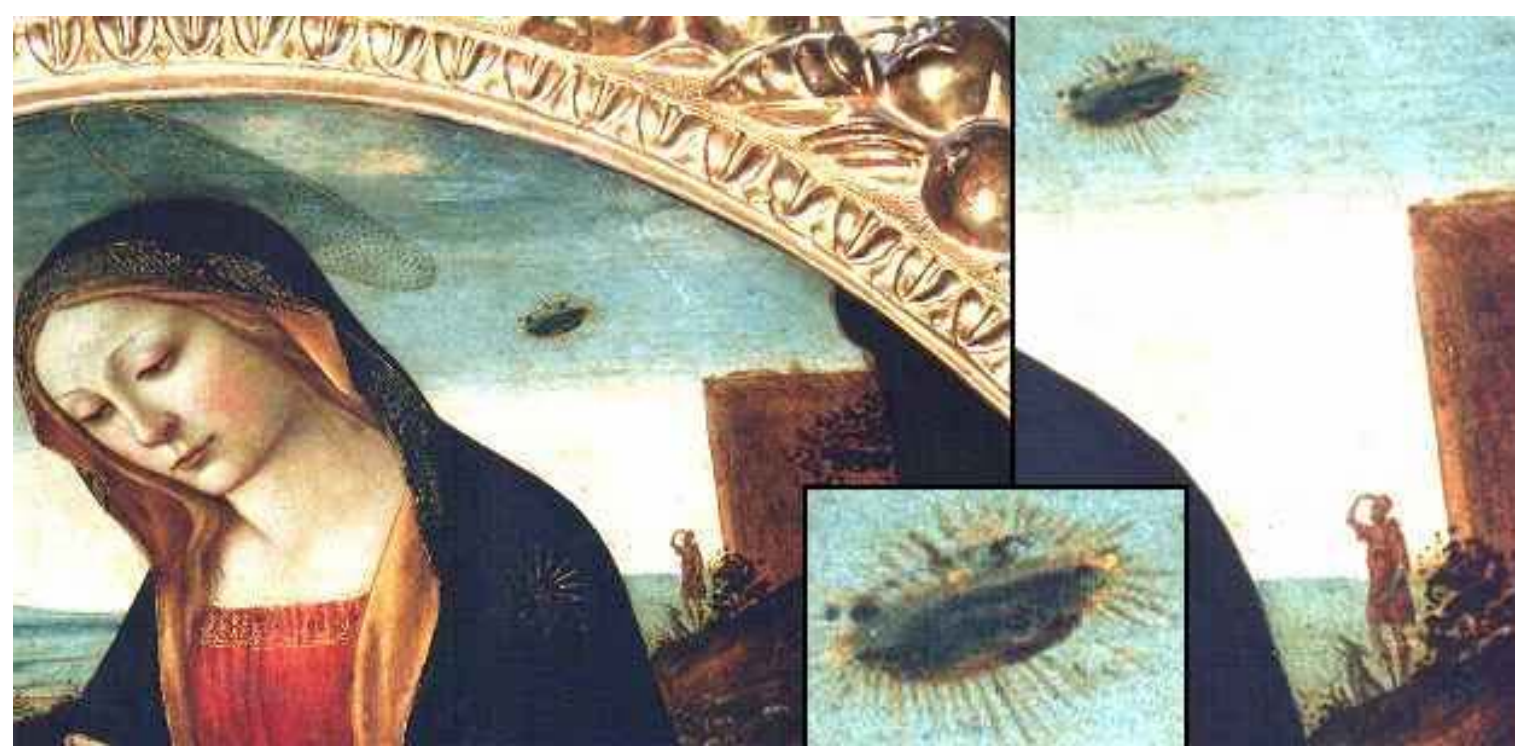

Figura 11 - Ampliações da pintura Madonna e o Menino (séc. XV)- figura acima descrita Nas ampliações pode-se notar que o objeto faz parte do contexto da tela. Observe a luminosidade representada pelo autor. Note também que uma pessoa observa o objeto cobrindo o rosto com as mãos, devido à luminosidade do mesmo. Ao lado da testemunha existe um cachorro em posição de alerta. 


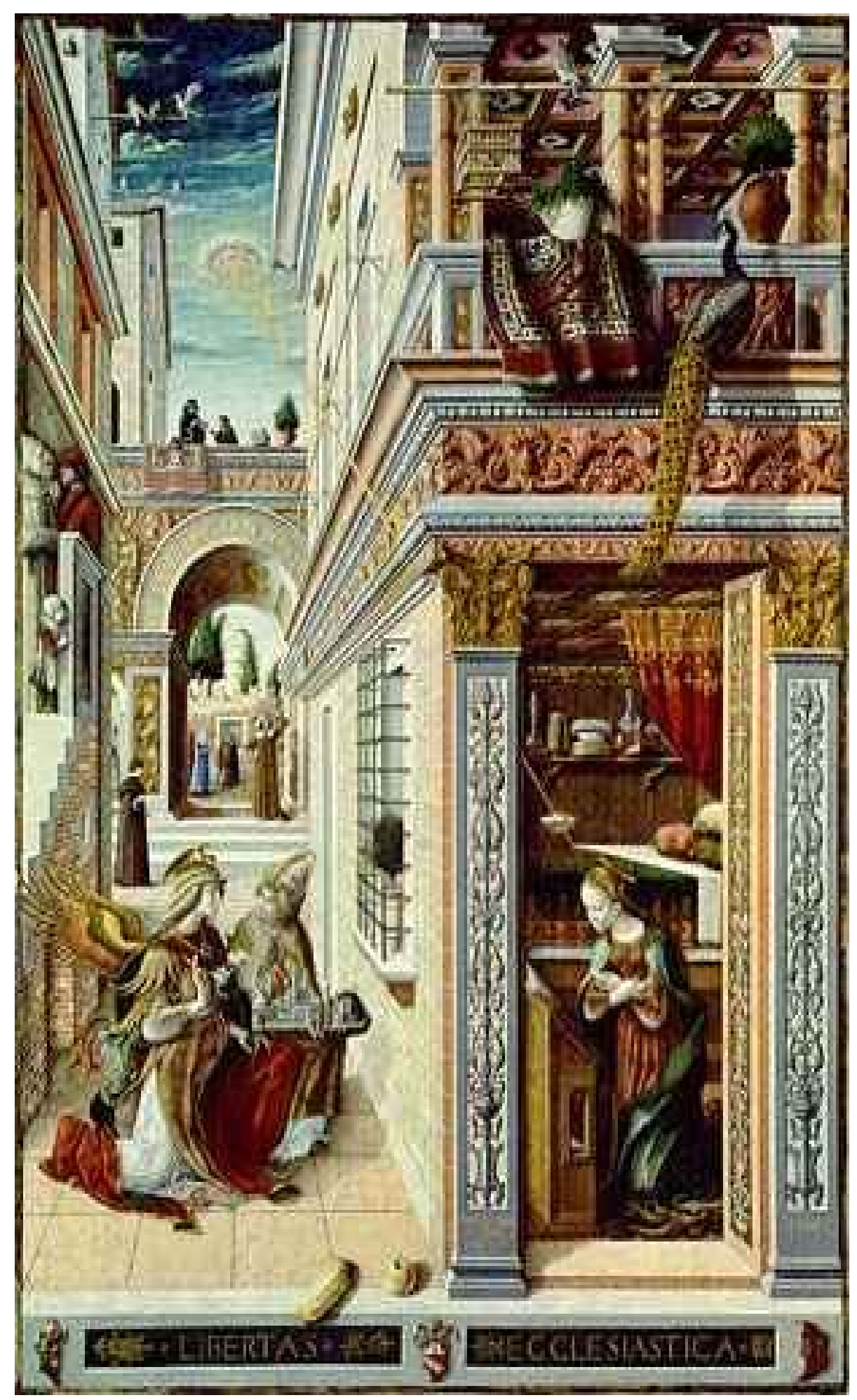

Figura 12 - Quadro A anunciação (1486), de Antonio Crivelli 

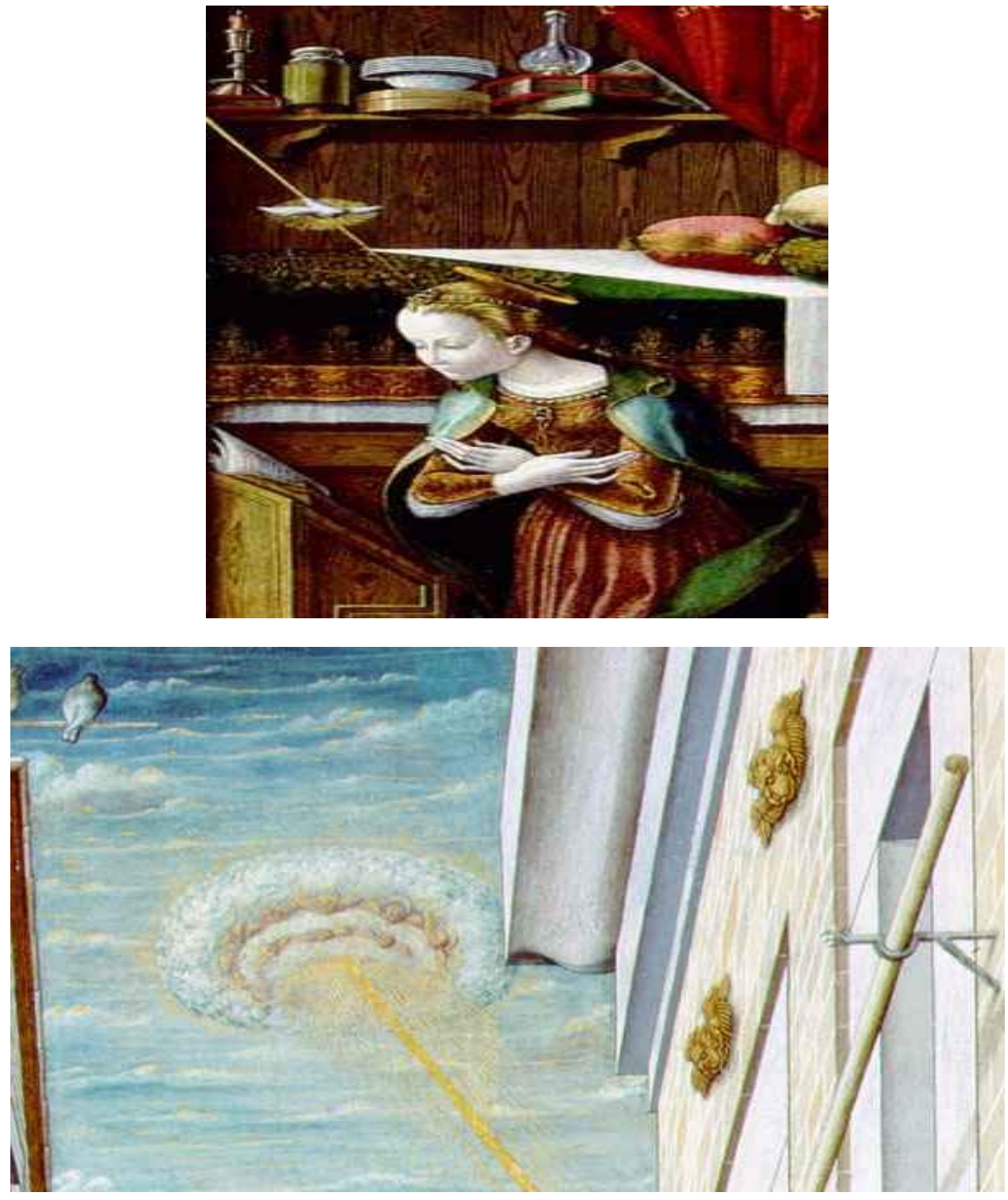

Figura 13 - Ampliação do quadro A anunciação (1486), de Antonio Crivelli. O quadro acima representa a virgem Maria sendo iluminada pelo Espírito Santo. Note que o raio de luz parte de um objeto discoidal suspenso no céu e passa pela Pomba (que representa o Espírito Santo). As duas últimas figuras são ampliações do quadro para facilitar a visualização.

Por conseguinte, esta possibilidade de encontrar indícios de naves e seres extraterrestres em qualquer época da nossa história é para a ufologia, apenas, mais uma das tentativas da comprovação do fenômeno. 


\subsection{Vieses}

\subsubsection{Científico}

Questionar a cientificidade da ufologia, isto é, sua validade científica, seria um trabalho para uma tese de doutorado, ou mesmo, para um metodólogo da Ciência (devido à complexidade do objeto). Tampouco a mim interessa a realidade física dos discos voadores e seus tripulantes. Meu objetivo neste capítulo é de abordar e demonstrar como a ufologia é vista e reconhecida nos parâmetros científicos nacionais e mundiais.

Já houve época em que se afirmava ser o nosso planeta o centro único e imóvel do universo, sede exclusiva de todo pensamento inteligente. Hoje, entretanto, a opinião dos cientistas consolidou-se na hipótese de que a vida surge em condições que há possibilidades de adaptações e reproduções viáveis ao crescimento de qualquer ser vivo (por exemplo, a água e quantidade de oxigênio) (Lisboa \& Andrade, 1986).

Não obstante, existem alguns indícios concretos para confirmar tais afirmações. Provas de vida fora da terra só temos três: a descoberta da absorção clorofiliana nas zonas verdes de Marte; as células fossilizadas encontradas em alguns meteoros carbônicos, e estranhos sinais modulados de rádio, vindos do espaço. Além disso, existe toda uma série de indícios secundários, reafirmando estas conclusões.(Lisboa \& Andrade, 1986: 193)

Segundo Lisboa \& Andrade (1986) - o universo pulula de vida. Existem milhões de galáxias desconhecidas e, o nosso sistema solar é considerado um mísero conjunto de grãos de areias em toda dimensão do universo. Existem somente na Via-láctea milhões e milhões de estrelas, muitas das quais certamente possuem sistemas planetários próprios.

O estudo do universo é composto por várias ciências: a matemática, a física, a química, a astronomia, a exobiologia (estudo dos efeitos de ambientes extraterrestres em organismos vivos e do potencial da vida em outros planetas). Estas ciências entendem que a vida passa por um processo de evolução, partindo de formas inferiores (tais como as bactérias), para outras mais avançadas e inteligentes (a raça humana, por exemplo). 
Inúmeros são os mistérios que circundam o nosso sistema solar (em Marte foram registrados clarões que possuem características semelhantes a explosões de bombas nucleares, fotos de misteriosos canais de irrigação, e enigmáticas pirâmides. Provindos da Lua foram observados e diagnosticados água congelada, figuras geométricas que surgem e desaparecem e brilhantes fachos luminosos) (Lisboa \& Batista, 1986).

Segundo Ufogenesis (1996) os discos voadores são apontados hoje como provas de que possivelmente existam seres inteligentes no espaço. Suas características de superioridade tecnológica colocariam a questão da existência de seres inteligentes em outros planetas.

A ciência mantém uma postura de descrédito frente aos fenômenos ufológicos, uma vez que para ela, a ufologia não possui características mensuráveis que possa provar a existência de extraterrestres. A pesquisa sobre óvnis é encarada hoje, tanto mundialmente como no Brasil, como algo intelectualmente pouco respeitável e impassível à cientificidade (Gepuc, 2000; Landsburg, 1976).

Esta problematização que ocorre na ufologia faz com que sua área de pesquisa e estudo fiquem fragilizadas para eventuais comprovações da existência de óvnis e, conseqüentemente, de uma civilização extraterrestre.

Alguns estudiosos acreditam que a nossa ciência acadêmica-universitária é limitada e, até mesmo, incapaz para estudar e comprovar a existência de objetos voadores não identificados (algumas destas limitações são o fato da impossibilidade de reprodução do fenômeno, à vontade do pesquisador, nos laboratórios), além de ter seu objeto de estudo fenômenos que, por sua natureza são similares àqueles que pertencem ao campo da religião (mediunidade, clarividência e viagens astrais) (Thompson, 2002; Romero, 1999; Uchoa, 1981).

O material empírico da ufologia não é o próprio disco voador e/ou seus supostos tripulantes, mas os relatos que são coletados sobre "experiências ufológicas" ou observações (Neto, 1984). São as chamadas testemunhas, que para serem consideradas como provas precisam ser avaliadas pelos entrevistadores, questões de sua idoneidade perante a sociedade (são avaliados, por exemplo, se tal pessoa é respeitada em sua comunidade, se é casada, 
profissão, e ceticismo perante os óvnis). As fotografias, filmagens, análise do solo e de vegetação, e até mesmo a hipnose são, também, alguns dos instrumentos utilizados para eventuais estudos do fenômeno.

Além da confiabilidade da testemunha, outro aspecto que avaliam é o viés do entrevistador. As conclusões extremamente céticas e de pessoas que acreditam piamente na existência de óvnis são ponderadas no critério do bom senso (Butlar, 1980).

Outros meios que são bastante utilizados pelos ufólogos a fim da coleta de dados são as vigílias e as pesquisas de campo. As vigílias se efetuam através da observação do céu e do meio ambiente. Normalmente feita em grupo, ufólogos acampam (podendo ser algumas horas ou mesmo dias) nas proximidades onde há relatos de aparecimento de ufos, e com binóculos, filmadoras e outros apetrechos tecnológicos buscam uma possível visualização destes. A pesquisa de campo se constitui pela coleta de informações de situações vivenciadas por terceiros que de alguma forma tiveram alguma experiência com ocorrências ufológicas. É recomendável o uso de questionários, gravadores, e máquinas fotográficas para registrarem as possíveis informações dadas pelas testemunhas.

Para a ufologia os contatos ou observações podem se dar em sete diferentes graus: (Neto, 1984; Buttlar, 1980; Infa, 2004).

Contato imediato de $\mathbf{1}^{\circ}$ grau: o simples avistamento de um suposto ufo, a grande distância, sem que este interfira no meio ambiente.

Contato imediato de $2^{\circ}$ grau: um aparecimento de um suposto ufo, que tenha deixado uma marca física qualquer, como efeitos físicos em animais, queimadura na pele do contactado, vegetação chamuscada ou podada, galhos de árvores quebrados, animais assustados, além de faróis de veículos, motores e rádios que se desligam durante algum tempo.

Contato imediato de $3^{\circ}$ grau: observações de supostos ufos onde seus tripulantes são vistos no interior do óvni ou nas proximidades. Neste contato poderia existir uma possível comunicação entre o contactado e os tripulantes do ufo. 
Contato imediato de $4^{\circ}$ grau: quando um suposto contactado além de uma possível comunicação com os E.T.s conheceria, também, o interior da nave. É o que os ufólogos chamam de abdução ou seqüestro. Supostamente os "abduzidos" são submetidos a diversos exames (pele, sangue, extração de sêmen e óvulos). Para muitos ufólogos, normalmente, antes de serem colocados fora da nave, às memórias destes abduzidos são apagadas, sendo possível recordar dos fatos mediante sessões de hipnose.

Contato imediato de $5^{\circ}$ grau: o suposto contactado seria transportado pela nave sem sair da órbita da Terra. Há, também, segundo os ufólogos a implantação de "chips" nos abduzidos. Estes possíveis "chips" seriam eletródios utilizados para acelerar a evolução cultural do subconsciente, desenvolvendo assim, percepções de novas dimensões e fenômenos extra sensoriais como, por exemplo, a clarividência. Estes supostos implantes muitas vezes não são físicos e há alguns ufólogos que acreditam que sirvam para monitoramento.

Contato imediato de $6^{\circ}$ grau: o suposto contactado faria um passeio pelo espaço a bordo da nave, deixando a órbita da Terra.

Contato imediato de $7^{\circ}$ grau: o suposto contactado visitaria o planeta de origem dos E.T.S, sendo apresentado a "civilização" deles. Esta suposta visita se daria através de "viagens astrais", ou sonhos, onde o contactado saberia que seu corpo físico ficou em nosso planeta, e somente o seu espírito entrou em contato com os E.T.s.

É importante salientar que estes "contatos" acima citados são utilizados apenas como suporte de uma possível padronização de métodos que visam à comprovação de óvnis. É complicado para um ufólogo científico se deparar com testemunhos que dizem ter realizado viagens a outros planetas, enquanto seu corpo físico permaneceria deitado sobre uma cama dormindo.

Os ufólogos trabalham também com tipologias. Segundo Neto (1984)

"Os seres extraterrestres são de variados tipos e os ufólogos classificam-nos segundo diversos critérios: local e data de aparecimento, descrição física (altura, feições faciais, presença ou não e tipo de cabelos, cor e textura de pele, vestimenta, etc) e comportamento perante seres humanos (evasivos, amigáveis, ou agressivos)". (p. 32) 
As naves também teriam, segundo Neto (1984), suas tipologias feitas a partir da descrição física dos objetos (formas, tamanhos), local e data do avistamento.

A maioria das provas sobre óvnis já disponíveis assume, então, a forma de relatórios em que o depoimento de testemunhas e investigadores é de importância crucial. Estas tipologias acima descritas são utilizadas pelos ufólogos a fins de padronizar os dados coletados dos contactados. Na ufologia científica, os ufólogos buscam métodos de cunhos estatístico que buscam comprovar a veracidade de observações tentando estabelecer padrões no tempo e espaço, isto é, a observação de um mesmo fenômeno por diferentes pessoas em uma determinada área geográfica e um determinado período de tempo (Neto, 1984).

\subsubsection{Religioso}

No discurso ufológico, a ufologia não é considerada uma religião, mas uma disciplina científica que, voltada para o estudo do fenômeno óvni, se depara com fatos peculiares às religiões (paranormalidades em geral, como premonições, viagens astrais, etc). Seu material empírico seriam os próprios contatos mediúnicos e, suas pesquisas fariam através de experiências paranormais. Estas particularidades são abordadas perante a ufologia não como objetos de um mundo sobrenatural, opostas ao mundo físico, mas sim da convicção de que a realidade é maior do que o homem pode perceber (Neto, 1984).

Assim, ao contrário de se considerar uma religião, a ufologia converte dados místico-religiosos à categoria de "fenômeno ufológico" e trata de estabelecer fronteiras entre sua "disciplina" e os "objetos místicos". Ao mesmo tempo em que seriam encontradas supostas evidências físicas, como marcas de círculos no solo, cicatrizes em animais e em seres humanos, rastreamento de radares, fotografias e vídeos de óvnis, por outro lado à ufologia se depara com aspectos que o tornam diferentes dos objetos reais (tais como supostas interferências em aparelhos elétricos, possíveis teletransportes de objetos e de pessoas, possibilidades de efeitos de cura, velocidades de decolagens desconhecidas, supostos desenvolvimento de atividades psíquicas do contactado, dentre outras) (Neto, 1984). 
Convém observar que no discurso ufológico místico, a ciência institucionalizada é considerada limitada e ultrapassada, sendo a ufologia considerada um novo tipo de ciência, voltada para uma nova era, orientando o indivíduo para uma fase de mudanças para um novo milênio, no qual haverá um mundo voltado para a harmonia e paz descartando, conseqüentemente, o materialismo e sentimentos como a inveja e o ódio.

Seus seguidores (na linha mística) correlacionam-se com o movimento new age. Tal movimento, segundo Siqueira (2003),

“(...) poderia ser caracterizado como um conglomerado de tendências que não teria textos sagrados ou lideres, nem organização fechada ou estrita, nem dogmas. Tratar-se-ia, segundo alguns autores, de mais uma sensibilidade espiritual, do que um movimento espiritual estruturado. Expressaria atitude ou desejo de integração e de harmonia, buscando articular o pessoal e o privado com o ecológico e o cósmico, a sensação de liberdade com a experiência do divino, do sagrado, do misterioso ou do numinoso" (p. 19).

Assim, as pessoas que se identificam com esta linha ufológica, em geral identificam-se também como "alternativas" e adotam, em pelo menos alguns aspectos um estilo de vida de recusa a sociedade de consumo. Segundo (Neto, 1984: 33) o autor tenta mostrar esta melhor diferença na seguinte tabela:

\begin{tabular}{cc}
\hline \hline Tabela 2 - Tipologias da Sociedade \\
\hline \hline Sociedade de Consumo & Sociedade Alternativa \\
\hline Industrial & Natural \\
\hline Ocidental & Orientalista \\
\hline Individualista & Comunitária \\
\hline Racionalista & Espiritualista \\
\hline \hline
\end{tabular}

Por conseguinte, a explicações destas diferentes correntes existentes na ufologia são fundamentais para tentar entender como é feita e subdividida a pesquisa ufológica no âmbito mundial e nacional. Para alguns, a religiosidade e a ciência caminham em diferentes vertentes, mas para outros, somente esta unificação é que encontrará as chaves das respostas do fenômeno óvni. 


\subsection{Parâmetro da Ufologia Mundial e Nacional}

\subsubsection{Parâmetro Mundial}

O fenômeno óvni reflete em quase todos os lugares do planeta, desde os Pólos até o Equador. E, além dos supostos avistamentos, em muitos destes países existiram ou existem estudos ufológicos. Bélgica, Chile e França, por exemplo, já admitiram a existência do fenômeno, e já liberaram arquivos antes secretos (França), além de promoverem comissões de investigações para conhecimento da população. Mas, são os Estados Unidos os mais envolvidos com a questão, investigando, captando sinais por radares, resgatando "possíveis naves acidentadas" e segundo muitos, promovendo uma grande e maciça política de acobertamento e ridicularização sobre o estudo dos óvnis.

Nas décadas de 40 e 50 a opinião pública americana predominante era de que esse misterioso assunto merecia ser melhor pesquisado. Com os astronautas praticamente desbravando o espaço a ponto de transformarem a lua em campo de pouso para os exploradores humanos, houve uma inevitável escalada da expectativa pública por uma explicação completa do persistente mistério dos óvnis.

Por mais de vinte anos, de 1948 a 1969, a força aérea norte-americana encarregou-se de investigar a questão dos óvnis. Durante a maior parte desse período à unidade responsável era uma força tarefa denominada Projeto Blue Book. Em pouco tempo desenvolveram métodos rápidos e concisos de avaliação. Os investigadores consultavam dados astronômicos, monitoravam os vôos das aeronaves e verificavam os registros meteorológicos. A equipe do Projeto Blue Book identificava os relatos fraudulentos e os que podiam ser atribuídos a fenômenos naturais, mas o grupo funcionava partindo do pressuposto de que os óvnis não existiam. Assim, para a pequena porcentagem de casos não solucionados, os investigadores tinham duas opções: ou admitiam que não tinham conseguido identificar o objeto ou adotavam alguma explicação remotamente plausível.

Apesar dos inúmeros relatos, devido à guerra fria muitos achavam que o fenômeno eram armas secretas dos soviéticos. Embora não tivessem nenhuma prova que eram super armas, apenas a existência do fenômeno poderia ser 
usada como ferramenta de propaganda pelos russos. O mundo estava empenhado na guerra fria e tudo era pensado em termos de ataque e defesa, segurança nacional, infiltrações e estratégias do inimigo. Tentando evitar histeria causada pelo desconhecido. Segundo Gepuc (2000) a força aérea iniciou uma política de descrédito de testemunhas dos tais eventos, decretando, assim, o fim do projeto Blue Book alegando não haver dados concretos que comprovassem a existência de óvnis.

Segundo Romero (1999), a existência de alguns documentos americanos antes considerados ultra-secretos, que por algum motivo chegaram nas mãos do público exemplifica uma política de acobertamento: em uns dos relatórios do Departamento de Pesquisa e Análise do Grupo Central de Inteligência (antecessor a CIA) no item recomendação, pode-se ler:

“(..) Em virtude da natureza extremamente perturbadora do fenômeno e de nossa incapacidade de agir, todo o assunto deve ser classificado na mais alta categoria existente de segredo de Estado, sendo salvo, inclusive, de uma rigorosa campanha de propaganda centralizada na negação de tudo. A campanha deve ter penetração social total, de modo que continue sendo eficiente mesmo se for registrado um elevado número de desaparecimento de pessoas ocorrido naqueles lugares. 4) Sob circunstâncias alguma se deve permitir que o público se conscientize da provável seriedade desta situação, assim como de nossa incapacidade de agir. A única maneira de nos certificarmos de que ele continuará ignorante será a imposição do mais alto nível de segurança jamais alcançado. Se pretendermos continuar dando a impressão de que o governo pode propiciar ao seu povo a segurança essencial, isto deve ser feito a todo e qualquer custo" (p. 120)

Após terem estudado 237 das melhores observações, os técnicos do projeto descobriram que 32\% delas podiam ter uma explicação astronômica, 35\% eram balões, sondas, aviões, foguetes, 13\% não tinham explicação por falta de maiores informações e $20 \%$ resultariam ser algo incomum e não identificado.

Com os apenas $20 \%$ de casos sem explicação um famoso astrofísico chamado Joseph Allen Hynek (considerado entre os ufólogos uns dos grandes Papas da ufologia) começou a investigar as possíveis alegações de óvnis, declarando que a força aérea não investigava o fenômeno corretamente.

Nas demais décadas, principalmente as de 70 e 80, graças a Hynek, novos métodos de coleta de dados começaram a ser utilizados e diferentes 
especulações acerca da natureza do fenômeno passaram a ser questionadas. (Segundo ele era preciso aprofundar as pesquisas, padronizar as informações, e torná-las disponíveis a manipulação através de computadores, para que atributos comuns como cores, formas, velocidades pudessem ser analisadas) (Mistérios do desconhecido, 1992: 121).

Para muitos ufólogos não somente o Projeto Blue Book, mas alguns outros (tais como o Projeto Sign, e o Projeto Grudge - estes visando, também, estudar o fenômeno) foram criados para desinformação e acobertamento de evidências. Claro, sempre mantendo uma postura cética e visando associar os fenômenos a causas naturais e humanas. Em muitos casos, as explicações oficiais oferecidas chegavam a ser uma atrocidade ao bom senso. Em 1954 a Força Aérea americana admitia oficialmente já haver estudado mais de 10000 "casos" de observação destes estranhos engenhos aéreos, e fontes civis independentes diziam que este número deveria ser elevado para 100000.

Mas qual o verdadeiro interesse em ocultamentos dos fatos ufológicos?

Para (Uchoa, 1981)

“(...) o avanço técnico na construção e governo desses aparelhos, cujas manobras e fenômenos de várias ordens acompanham suas aparições, transcendem de muito ao que nossa técnica humana poderia realizar. A nação que possuísse tal capacidade de fazer e atuar, transformando esses objetos em armas de poder, jamais esperaria, pacífica, que outra se Ihe igualasse" (p. 40).

Ou seja, a busca pela supremacia tecnológica, visando poder e conhecimento, poderia, então, dominar o mundo, ditando-lhe as leis que houvesse por bem impor, apoiada nesse avanço, nesse poder técnico-científico.

Desde 1947, milhares de relatos surgiram sobre o fenômeno. Segundo cálculos de pesquisadores seriam 10 milhões de registros conhecidos. Segundo estas estatísticas, a cada três minutos, alguém, em algum lugar do mundo, está tendo algum "tipo de contato com tripulante de óvnis". São relatos muito diversificados, que vão de simples luzes avistadas a noite e a distância, passando por supostos raptos de seres humanos, até casos de possíveis mutilações e mortes. Se existir alguma prova concreta acerca dos óvnis, são pouquíssimas expressivas estas as quais o público tem acesso. (Thompson, 1993: 20). 
Além da suposta "política de acobertamento" a ufologia defronta-se com a falta de reconhecimento público. Não há, por exemplo, nenhum ufólogo profissional, ou seja, uma pessoa que receba algum salário por simplesmente ser ufólogo. Vários dos estudiosos necessitam de um trabalho paralelo para poder se sustentar financeiramente. Não existem universidades que formam ufólogos tampouco uma categorização no registro de profissões que devem ser indicados na declaração de Imposto de Renda.

Não há como se ganhar a vida com ufologia, exceto para gurus e falsários que exploram religiosamente - e não cientificamente - a área. Este é uns dos casos mais complexos da ufologia, pois ao mesmo que se pretende estudar o fenômeno a sério, a desinformação e as fraudes são bastante comuns. Freqüentemente surgem gurus de seitas ufológicas que alegam serem "contactados ou representantes de E.T.s na Terra". Alguns casos são tão extremos que resultam em suicídios coletivos.

\subsubsection{Parâmetro Nacional}

O mundo ufológico se constitui de grupos voltados para o estudo e a pesquisa do fenômeno. Esses grupos, constituídos em associações, centros, sociedades, organizam web sites, promovem a publicação de revistas e realizam congressos, simpósios, e outros tipos de encontros, à semelhança das disciplinas científicas. Os trabalhos aí apresentados possuem toda a forma peculiar à produção científica - inclusive porque a maioria dos conferencistas se constitui de pessoas com formação universitária.

No Brasil, foi criado o "código de ética do ufólogo" em setembro de 1997. Este código contém regras de condutas, deveres e responsabilidades das pessoas que pesquisam a ufologia no território brasileiro. Contendo mais de 10 capítulos com varias seções, este define os diferentes tipos de pesquisa, fixam normas de condutas, promovem a análise e divulgação dos fenômenos, além de ter uma legislação que regulamenta a ufologia, uma vez que esta não está entre as ciências e técnicas reconhecidas oficialmente. 
O Brasil também já realizou investigações sobre o fenômeno óvni. A maioria de caráter confidencial e baseado na suposta política Norte Americano de acobertamento.

Segundo Ufo (2004), independente de qual partido esteja no poder em nosso país, militares dos Estados Unidos sempre estiveram envolvidos no levantamento de casuísticas brasileiras direta ou indiretamente, mantendo relações sigilosas com nossos militares sendo acionados por nosso governo para acompanhar ou resolver assuntos da área. (Para exemplificar esta questão, ufólogos acreditam que o caso Varginha-MG, no qual foram registradas criaturas supostamente alienígenas, militares norte-americanos acompanharam os procedimentos médicos ao lado de nossos militares, levando os supostos E.T.S para bases militares americanas no qual poderiam estudá-los com mais recursos (Ufo, 2004).

O primeiro projeto brasileiro que se tem notícia era o Sistema de Investigação de Objetos Aéreos não Identificados (Sioani), fundado e sediado em 1969, no $4^{\circ}$ comando aéreo regional (Comar) em São Paulo-SP. O Sioani era formado por militares e civis espalhados por diversas bases aéreas e aeroportos brasileiros, e começou a investigar casos ufológicos ocorridos na naquela época. O projeto foi uma iniciativa única, pois, apesar de ser na época de ditadura militar, havia colaboração mútua entre pesquisadores militares e civis, podendo estes até participar de reuniões e debates. Em 1972, as atividades do Sioani foram encerradas abruptamente. Dentre as hipóteses do fechamento há: forte pressão norte americana para ser totalmente secreto ou a mudança de governo, promovendo mudanças estruturais drásticas em diversas áreas.

O próximo projeto oficial brasileiro de pesquisas ufológicas é a Operação Prato, promovida pelo I Comando Aéreo Regional na floresta amazônica, precisamente nos arredores de Belém (PA), no ano de 1977. Seu surgimento foi motivado por uma onda ufológica sem precedentes na Região Amazônica, atingindo principalmente as pequenas comunidades litorâneas e rurais. Com a população alarmada, a Comar foi chamada para estudar o caso. A Operação Prato produziu inúmeros relatórios descrevendo vários incidentes com 0 fenômeno, obtendo, também, centenas de fotos e filmes com supostos óvnis. A 
atuação da Comar foi fundamental, pois serviu para acalmar os ânimos da população, mas as conclusões dos fatos estão trancadas até hoje a sete chaves.

Depois da Operação Prato, não temos mais notícias de projetos oficiais específicos para investigar discos voadores no Brasil, mas sabe-se que todos os casos ufológicos de grande importância, registrados no país, continuam sendo enviados para o Comdabra (Centro de Defesa Aeroespacial Brasileiro), que é o centro nervoso das operações de defesa da soberania área do Brasil (Ufo, 2004).

É importante ressaltar a atual campanha brasileira - UFOS liberdade de informação já (iniciada em maio de 2005 pela principal revista ufológica do mercado - a revista UFO) que visa à liberação de arquivos confidenciais para a sociedade civil. Ufólogos das mais diversas linhas de pensamento, além de requererem a abertura dos arquivos, propõem parcerias junto ao governo federal para que tenha uma parcela de contribuição na investigação e análise da problemática dos óvnis, suas implicações e conseqüências. A conclusão desta campanha será finalizada no ano de 2006, mas até o momento estão surgindo resultados positivos e concretos para a ufologia brasileira (por exemplo, a Força Aérea Brasileira - Fab já reconheceu oficialmente o fenômeno, e liberou alguns relatórios e documentos a respeito dos óvnis).

Segue abaixo os principais casos mundiais e nacionais sobre 0 aparecimento de óvnis. Não sendo este o objeto de estudo desta monografia, apenas realizar-se-á uma síntese com o objetivo de situar e demonstrar para o leitor as mais importantes casuísticas ufológicas da era moderna. 


\subsubsection{Casos Ufológicos}

\subsubsection{Roswell}

Este é o mais considerável e conhecido dos casos ufológicos de que já se teve notícia. Diversos pesquisadores da área se preocuparam em comprovar tais fatos, porém, até a presente data não houve nenhuma comprovação de serem ou não reais. As pesquisas que foram realizadas estão guardadas "a sete chaves" pelas entidades americanas. Roswell diz ter ocorrido no mês de julho no estado do Novo México - Estados Unidos, mais precisamente no dia dois do ano de 1947. Um ranchista que residia nas proximidades do local teria avistado luzes em um dia de tempestade forte. No dia seguinte, sai para ver os danos ocorridos em sua fazenda quando se depara com cerca de quatro quilômetros quadrados de destroços de uma suposta nave alienígena. Após um ou dois dias, esse ranchista comunica as autoridades sobre o ocorrido. Um oficial da inteligência, Major Jesse Marcel, foi enviado para investigar o local, e encheu seu carro com os destroços, levando-os para a base militar de Wright Field, em Ohio, onde se armazenavam os equipamentos inimigos capturados. Ao chegar à base com os destroços, foi feito um anúncio para a imprensa em que dizia que um objeto voador pousou em um rancho próximo a Roswell. Para acalmar a especulação da imprensa - e haviam chamadas chegando de todo o mundo - um pronunciamento oficial anunciou que o Major Marcel teria se confundido com destroços de uns balões meteorológicos, fazendo-o posar ao lado dos pedaços deste suposto balão. As autoridades logo pediram sigilo absoluto sobre o caso e, acreditam os ufólogos, que passaram a realizar pesquisas tanto "com os destroços da nave como em possíveis tripulantes". Até hoje, 58 anos depois do acidente, muitos ufólogos acreditam que as fotos abaixo, as quais podem ser encontradas no site Ufogenesis (1996), foram tiradas para desmentir o incidente: 

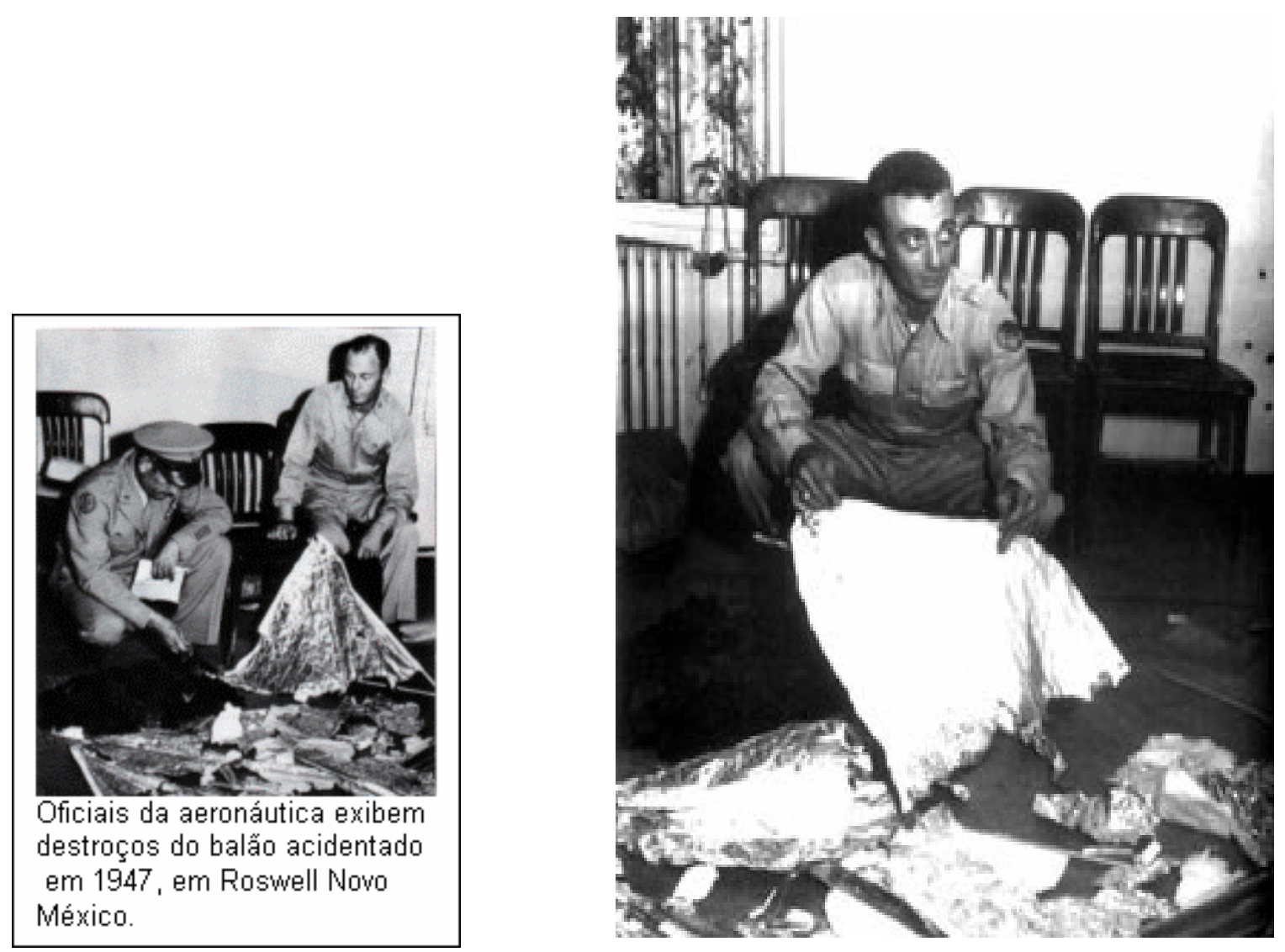

Figuras 14 e 15 - fotos que supostamente foram tiradas para desmentir o caso.

Em 28 de agosto de 1995, TVs de todo o mundo exibiram um documentário intitulado "Autópsia de um extraterrestre: realidade ou fantasia?", da TV britânica Fox Network. A fita mostra um suposto cadáver de E.T. que teria sido autopsiado na época do incidente de Roswell (1947). Atualmente, a maioria dos ufólogos considera a filmagem uma fraude.

\subsubsection{Varginha - MG}

No dia 20 de Janeiro de 1996, ocorreu o que para os ufólogos teria sido o segundo mais importante caso da ufologia: "O E.T. de Varginha".

Varginha é uma cidade mineira, com pouco mais de 120 mil habitantes, que viveu nesse janeiro de 1996 a sua glória mundial. Foi notícia nos mais 
importantes e conhecidos jornais do mundo dentre eles o New York Times, principal jornal dos EUA.

Varginha-MG transformou-se na capital brasileira da ufologia desde que o relato da visão de uma criatura estranha por três garotas ultrapassou suas montanhas e correu o mundo. Elas garantem que atravessavam um terreno baldio às 15 h30 do sábado 20 de janeiro de 1996 quando, a sete metros de distância, viram um ser marrom-escuro de pele viscosa. No mesmo dia, houve a ocorrência de chuvas torrenciais, que causou danos em residências e deslocou árvores centenárias de praças e ruas, antecipando um segundo achado, desta vez por dois soldados, do serviço de investigações da PM. Pouco acima do local da primeira captura, uma segunda criatura idêntica, de pele marrom-escuro, olhos vermelhos sem íris, córneas ou pálpebras, verticalmente saltados da caixa craniana, grossas veias proeminentes pelas espáduas, com pequenos orifícios em lugar de nariz e ouvidos, com boca delgada e minúscula, foi apanhada. Nesta mesma semana, avistamentos de óvnis, perseguições a objetos estranhos no céu, movimentação militar e uma série de outros acontecimentos anormais teriam sido relatadas por diversas testemunhas, tanto civil como militares. Segundo as testemunhas, o corpo de bombeiros havia capturado 2 criaturas extraterrestres levadas ao hospital, seguidos em comboio militar para a Unicamp(Universidade de Campinas), onde os supostos seres teriam sido analisados. Novos acontecimentos indicam que no acidente havia uma terceira criatura. Em fevereiro de 1996, quando um motorista fazia uma curva na estrada, os faróis de seu furgão iluminaram uma suposta estranha criatura a 50m de distância. Quando o assustado motorista freou, viu que a suposta criatura levantava a mão para proteger os olhos, "de cor vermelho-sangue", da luz para depois se perder no meio da noite. O motorista disse também que o provável ser tinha 3 ou 4 dedos em cada mão. Todos os órgãos envolvidos nesse caso dizem que nada de extraordinário ocorreu e até dizem que algumas afirmações chegam a ser absurdas e ridículas. 


\subsubsection{Barney e Betty Hill}

Considerado um clássico da casuística ufológica mundial, o caso Barney e Betty Hill foi uma das primeiras supostas abduções que tiveram repercussão mundial, inclusive na comunidade científica. No dia 19 de setembro de 1961, o casal Hill estava voltando da viagem de férias que fizeram no Canadá. Eles estavam na estrada de New Hampshire, com destino para Portsmouth, onde residiam. Era noite e os Hill pretendiam seguir viagem até de madrugada, pois o serviço de meteorologia havia dado um alerta sobre a possibilidade da região ser atingida por um furacão e eles queriam chegar em casa antes que isso ocorresse. Por volta da 02:30 horas, os dois avistaram um objeto luminoso voando no céu.

O casal Hill sai em alta velocidade com o carro, ouvindo um som - uma espécie de zumbido - que procedia do ufo. Mas logo o estranho ruído parou e eles, aliviados, acreditaram que tinham conseguido escapar daquele objeto. $O$ casal Hill não havia percebido que, entre os zumbidos, haviam se passado cerca de duas horas. Nos dias seguintes, Barney e Betty Hill passaram a ter pesadelos todas as noites. Incomodados com essa situação, eles foram buscar ajuda médica. Foram atendidos por psiquiatras, que resolveram usar hipnose regressiva como instrumento para tentar resgatar a memória do casal sobre o que realmente havia acontecido. A partir de sucessivas sessões de hipnose foi possível remontar passo a passo os acontecimentos do incidente ocorrido naquela noite.

A não ser por pequenas diferenças secundárias, os relatos de Betty e Barney coincidiram: na verdade, supõem que eles não haviam conseguido sair com o carro do local rapidamente. Os dois tinham ficado paralisados e foram supostamente levados para o interior do ufo por possíveis criaturas parecidas conosco. Os dois teriam sido submetidos a uma série de exames clínicos e interrogados por supostos E.T.s. Estes, segundo Betty, deixaram um provável mapa estelar de seu planeta de origem. Inicialmente não foi possível determinar se o mesmo era um mapa estelar real, pois não apresentava a menor similaridade com o que tínhamos de conhecimento sobre astronomia na época. Porém, vários anos após o incidente, com a evolução da astronomia e a divulgação de novas cartas celestes, pesquisadores conseguiram descobrir que o desenho de Betty Hill era realmente um mapa estelar extremamente preciso. Ele contém a 
constelação Retículo que se situa a 36 anos-luz de nosso sistema. Nossa astronomia não tinha esse conhecimento na época da abdução do casal Hill. (Infa, 2004).

\subsubsection{Ilha de Trindade-ES}

No dia 16 de janeiro de 1958, o navio da Marinha Brasileira Almirante Saldanha, estava na Ilha de Trindade no Espírito Santo. Por volta do meio dia, a tripulação observou um suposto objeto discoidal, de aparência metálico, que se aproximava pelo oceano. A seguir, foram relatadas interferências eletromagnéticas na embarcação, como falhas nas lâmpadas e no sinal de rádio. Ao todo, 47 membros da tripulação observaram o objeto, sendo alguns instruídos a fotografar o suposto objeto. Na época, a Marinha comprovou a autenticidade das fotos e o, então, presidente Juscelino Kubitschek, autorizou a publicação das imagens no jornal Correio da Manhã que, a título de ilustração, extraímos do site Infa (2004) e expomos abaixo:
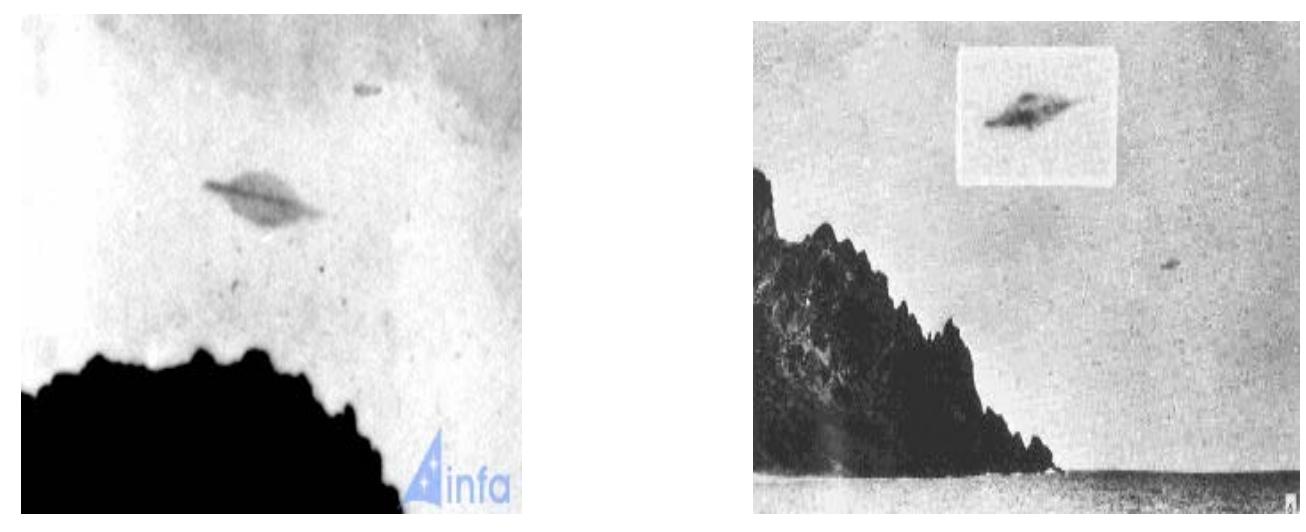

Figuras 16 e 17- Fotos do suposto óvni que foram consideradas autênticas para a Marinha Brasileira.

Salientemos aqui que, em 1971, um relatório foi publicado afirmando que as provas eram insuficientes para conclusões sobre óvnis. 


\subsubsection{A Noite Oficial dos Óvnis - Brasil}

A noite de 19 de Maio de 1986 ficará para sempre conhecida no Brasil como a Noite Oficial dos óvnis. Radares detectaram cerca de 21 óvnis concentrados sobre as regiões do Rio de Janeiro, São Paulo e sul de Goiás. Caças foram acionados para levantar informações, mas as supostas naves despistaram facilmente qualquer tipo de contato mais próximo (testemunhas relataram que as naves com uma tecnologia superior literalmente "brincavam" com os caças brasileiros). $\mathrm{O}$ fato foi comentado abertamente na imprensa pelo Brigadeiro Otávio Moreira Lima, Ministro da Aeronáutica, na época, que prometeu um relatório oficial explicando os estranhos acontecimentos. Este relatório nunca foi publicado, e o Ministério da Aeronáutica deu por encerrado o fato. 


\section{Ufo Turismo}

Neste capítulo serão abordadas as principais cidades mundiais e brasileiras que exploram o turismo ufológico como forma de geração de renda.

Alguns web sites utilizam o termo ufo turismo ou turismo ufológico, mas não há, ainda, entre os livros acadêmicos ou mesmo entre os turismólogos uma definição do que seriam estes.

O presente trabalho propõe a seguinte definição de ufo turismo ou turismo ufológico:

Turismo Ufológico, ou Ufo Turismo, refere-se a um segmento turístico que explora regiões nas quais há criações humanas que sugerem a ocorrência do fenômeno óvni ou, mesmo, indícios da presença ou avistamento de ufos. Tais indícios podem ser monumentos, construções, desenhos, manifestações energéticas, ou qualquer outra espécie de sinal de origem desconhecida que fascine pessoas em busca de tais peculiaridades.

Este tipo de público, segundo Ufogênesis (1996), é bastante exigente, de alto poder aquisitivo, formado principalmente pelas classes A, B e C. Possuem o hábito de viajar, e buscam neste tipo de segmento algumas das características próprias do turismo místico (paz interior, meditação, reflexão do estilo de vida, etc).

Os atrativos dependem da casuística do local. Algumas regiões com supostas incidências de ufo exploram além do misticismo, as belezas naturais, como cachoeiras, canyons, e formações rochosas, aproximando-se, também, do ecoturismo. Outras utilizam os próprios monumentos (ou qualquer outra manifestação) como atração turística.

Existem centenas de locais ditos "especiais", pelos seus constantes relatos de observações de naves extraterrestres. A maioria destes pontos é, em certa parte, fruto de uma mistificação e de dados pouco confiáveis, que a imprensa sensacionalista divulga em suas colunas. Atreladas a um intenso e lucrativo turismo, criado em torno do mistério e da mística que envolve certos locais, os óvnis, duendes, cristais, portais para outras dimensões e canalizações com 
entidades supostamente extraterrestres são os ingredientes necessários para um atrativo especial.

Dentre várias, podemos destacar certas localidades mundiais que exploram este tipo de turismo.

\subsection{Mundial}

\subsubsection{Roswell}

O caso da cidade de Roswell, no Novo México, nos Estados Unidos é um exemplo nítido da exploração turística utilizando a casuística ufológica.

A cidade que dá nome a um dos casos mais famosos da ufologia (onde teriam supostamente encontrado, em 1947, destroços de discos voadores e corpos de alienígenas, como já indicado) tem hoje boa parte de seu faturamento direta ou indiretamente vinculada ao turismo ufológico (Vigília, 1996).

O governo do município estimula o turismo na cidade, colocando à disposição dos turistas atrativos relacionado a esta história. Há museus aliens, exposições sobre E.T.s, lojas que vendem souvenirs com temáticas ufológicas, postes das ruas que são pintados de forma a lembrar olhos de alienígenas, dentre outros.

Em 1991, foi criado o International UFO Museum and Research Center, que até o ano de 2000 já tinha sido visitado por mais de 750 mil pessoas. Neste museu há informações sobre a história casuística da região, uma biblioteca, além de um centro de pesquisas sobre ufos e, claro, uma completa lojinha de souvenires, cujas fotos extraímos do site lufomrc (1996) e expomos abaixo: 


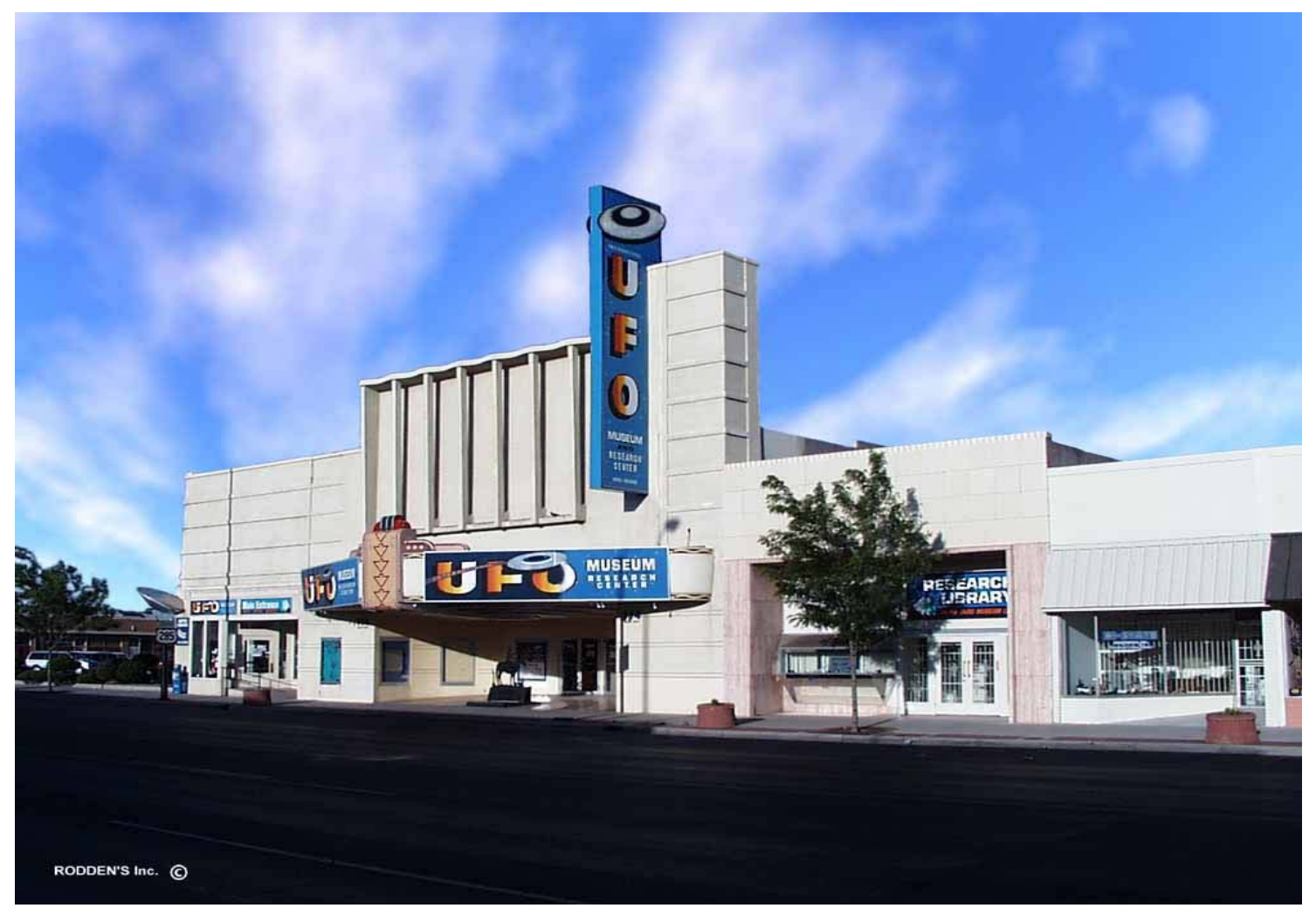

Figura 18 - Museu visto do lado de fora.

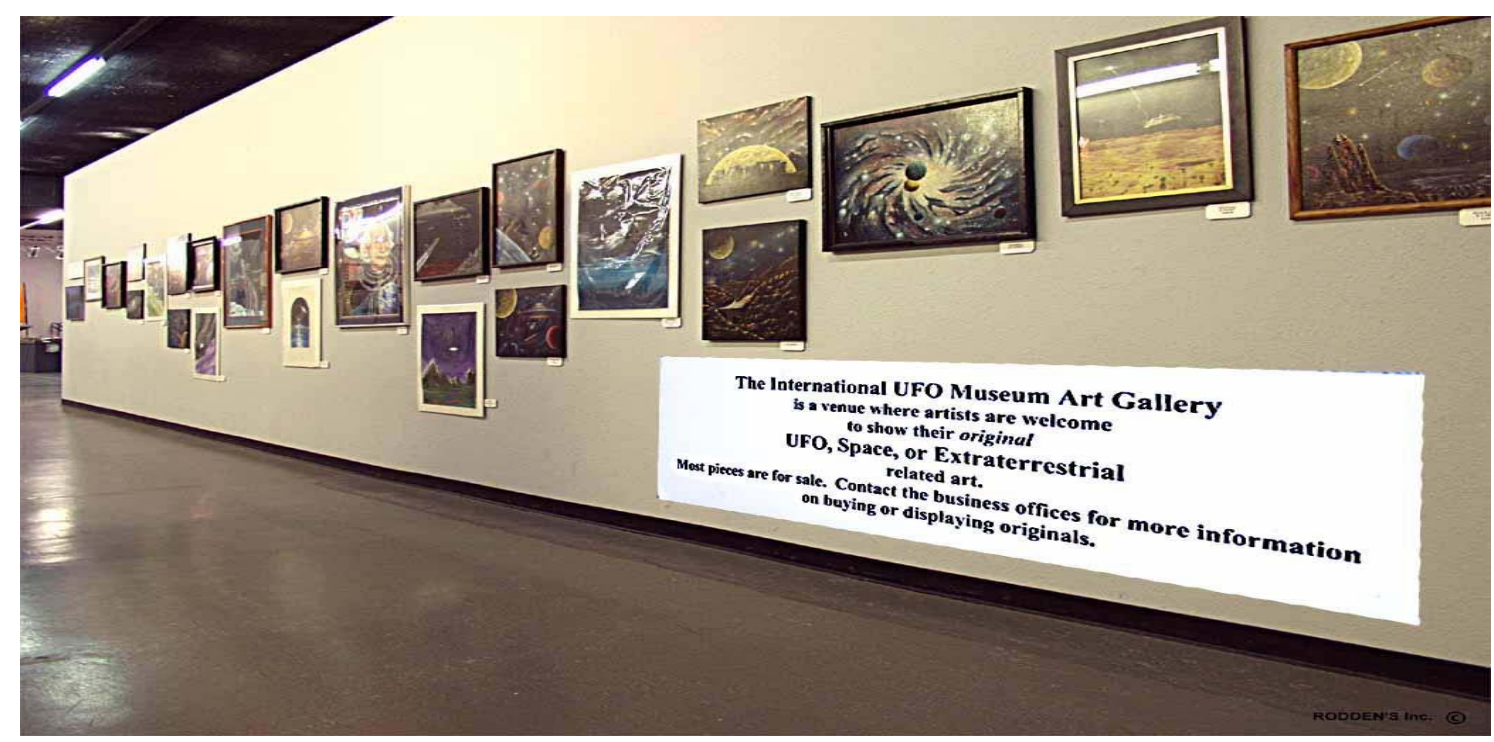

Figura 19 - Em uma das seções do museu (especificamente galeria de arte com temática ufológica). 


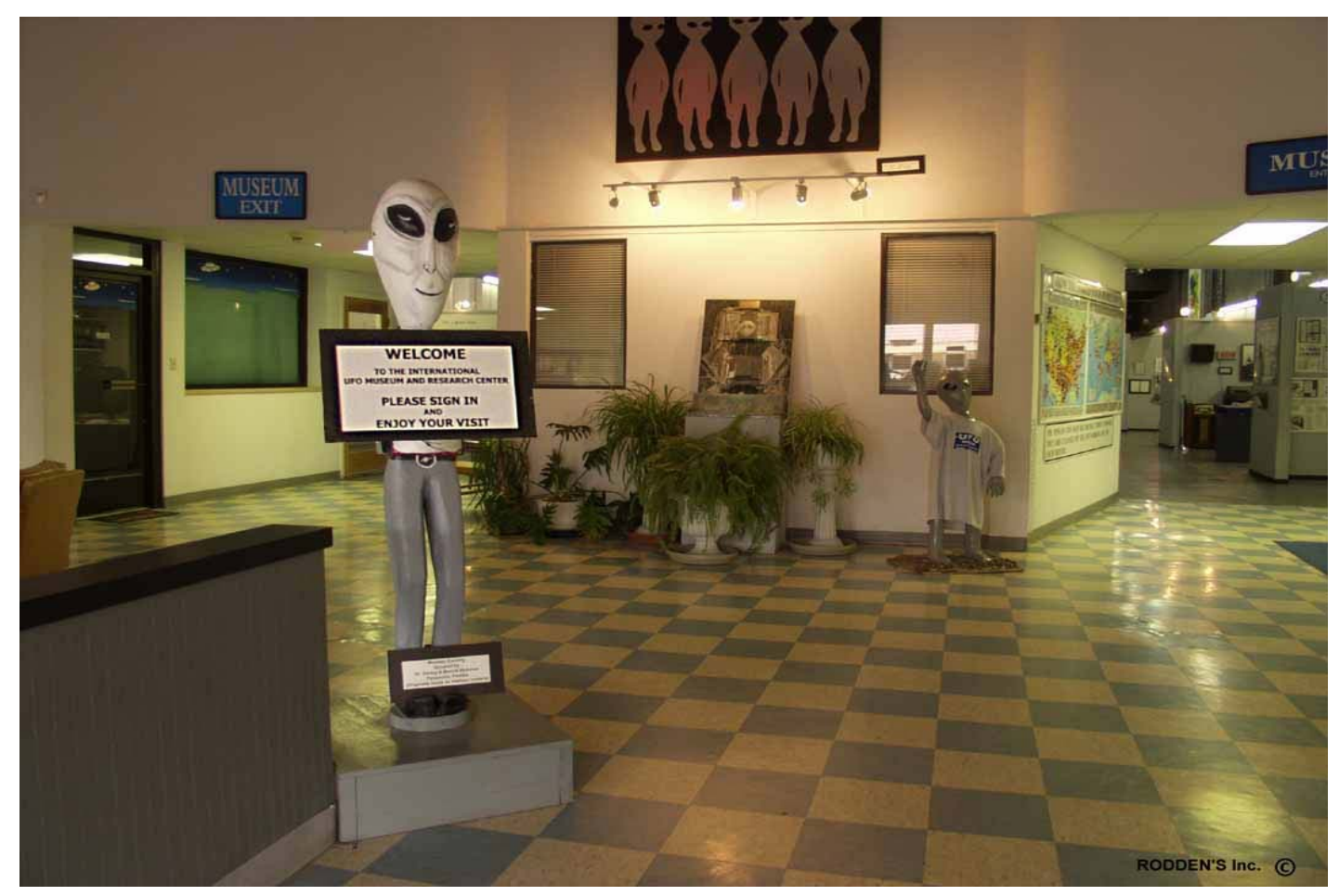

Figura 20 - Entrada do museu.

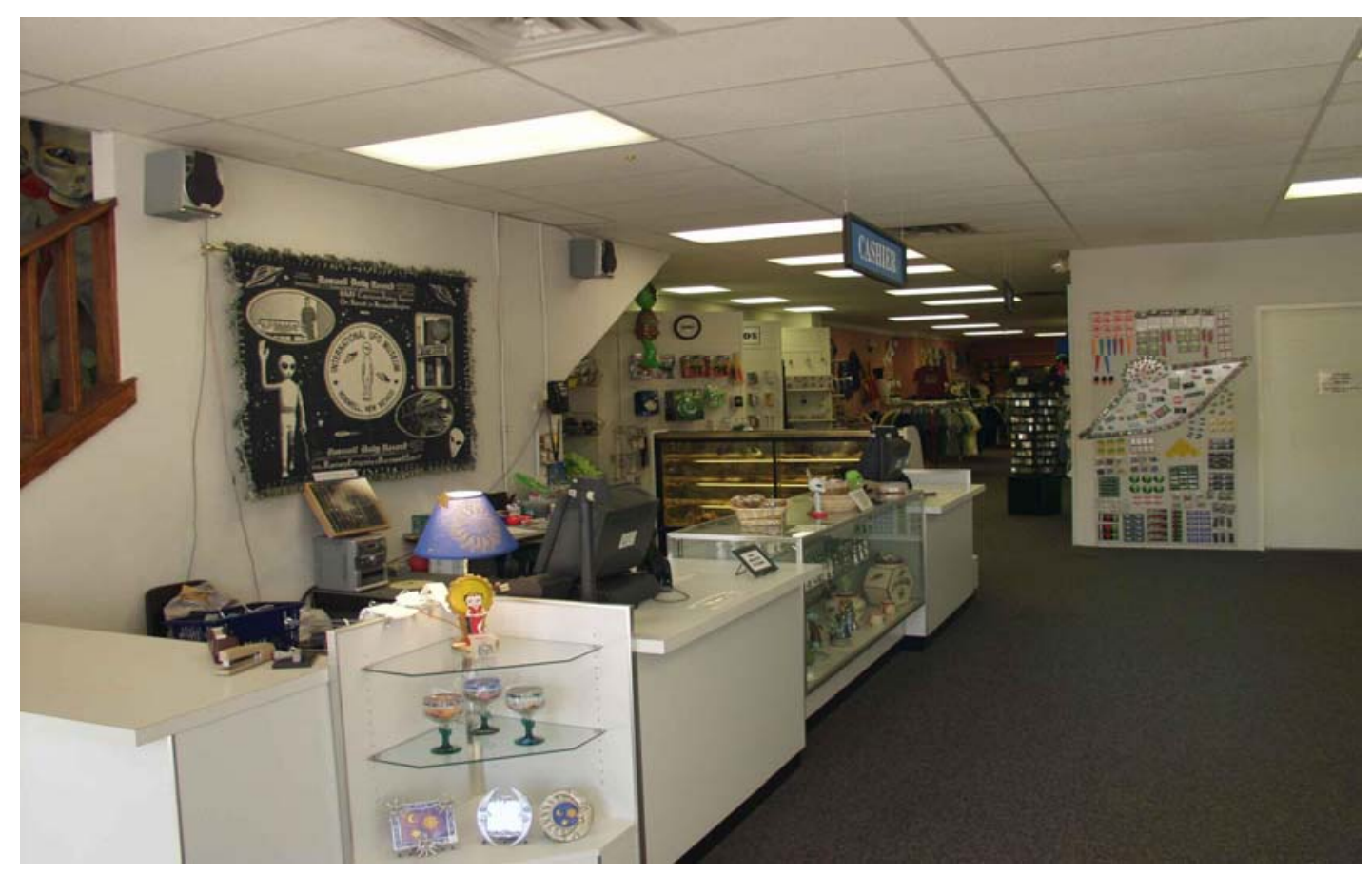

Figura 21 - Loja de Souvenir. 


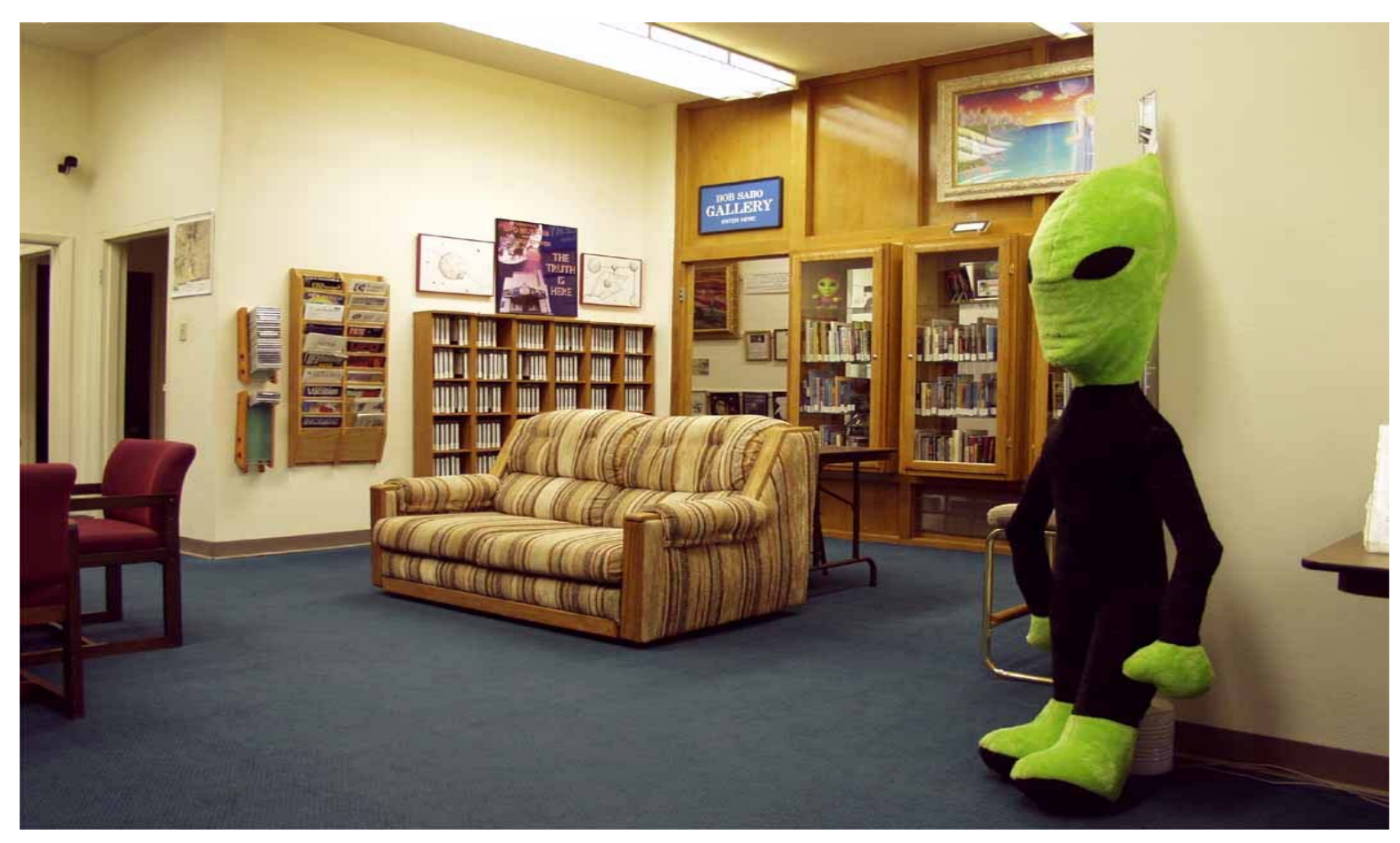

Figura 22 - Biblioteca.

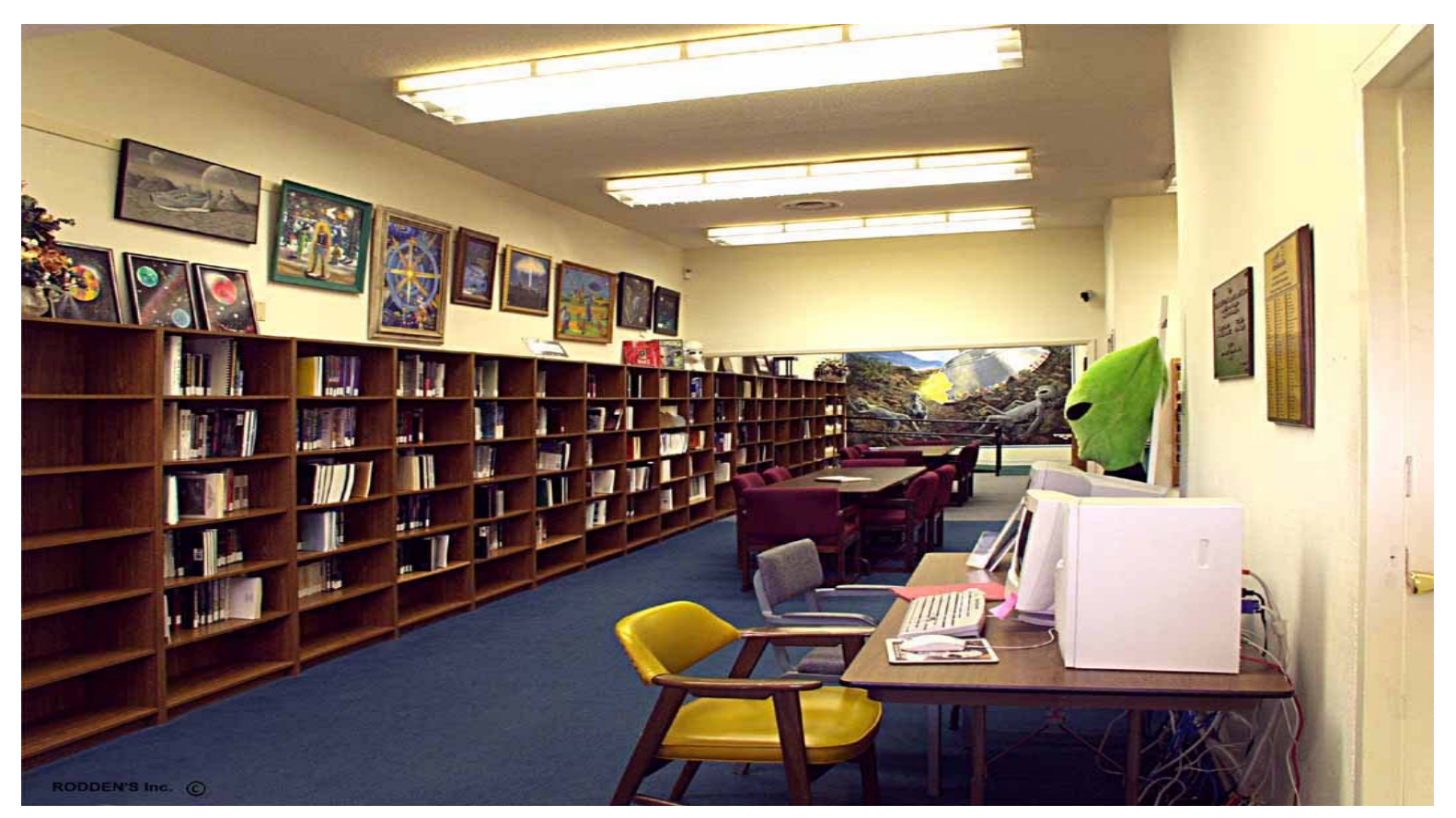

Figura 23 - Biblioteca. 


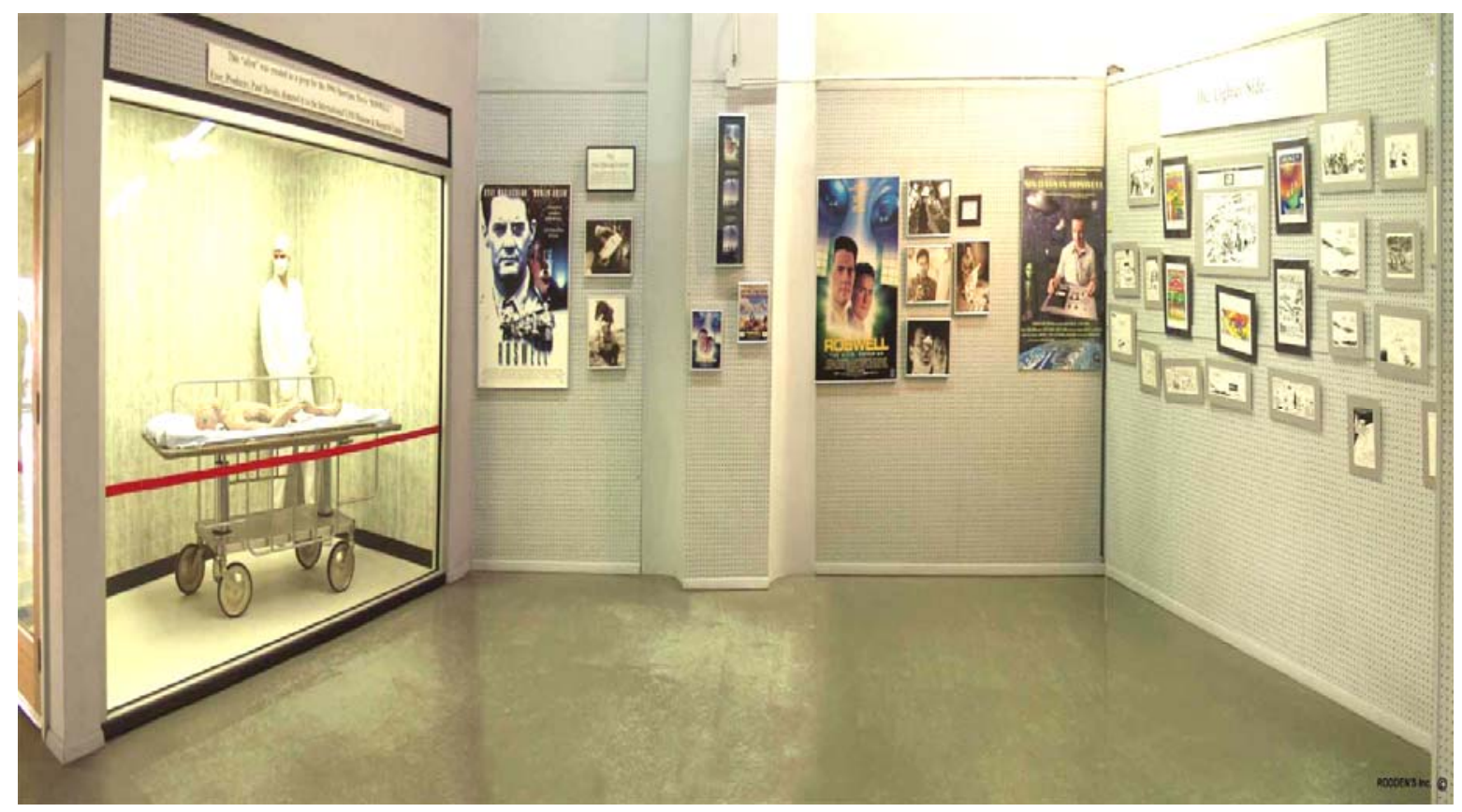

Figura 24 - Exposição de um suposto alien (com características iguais ao suposto E.T. caído na cidade).

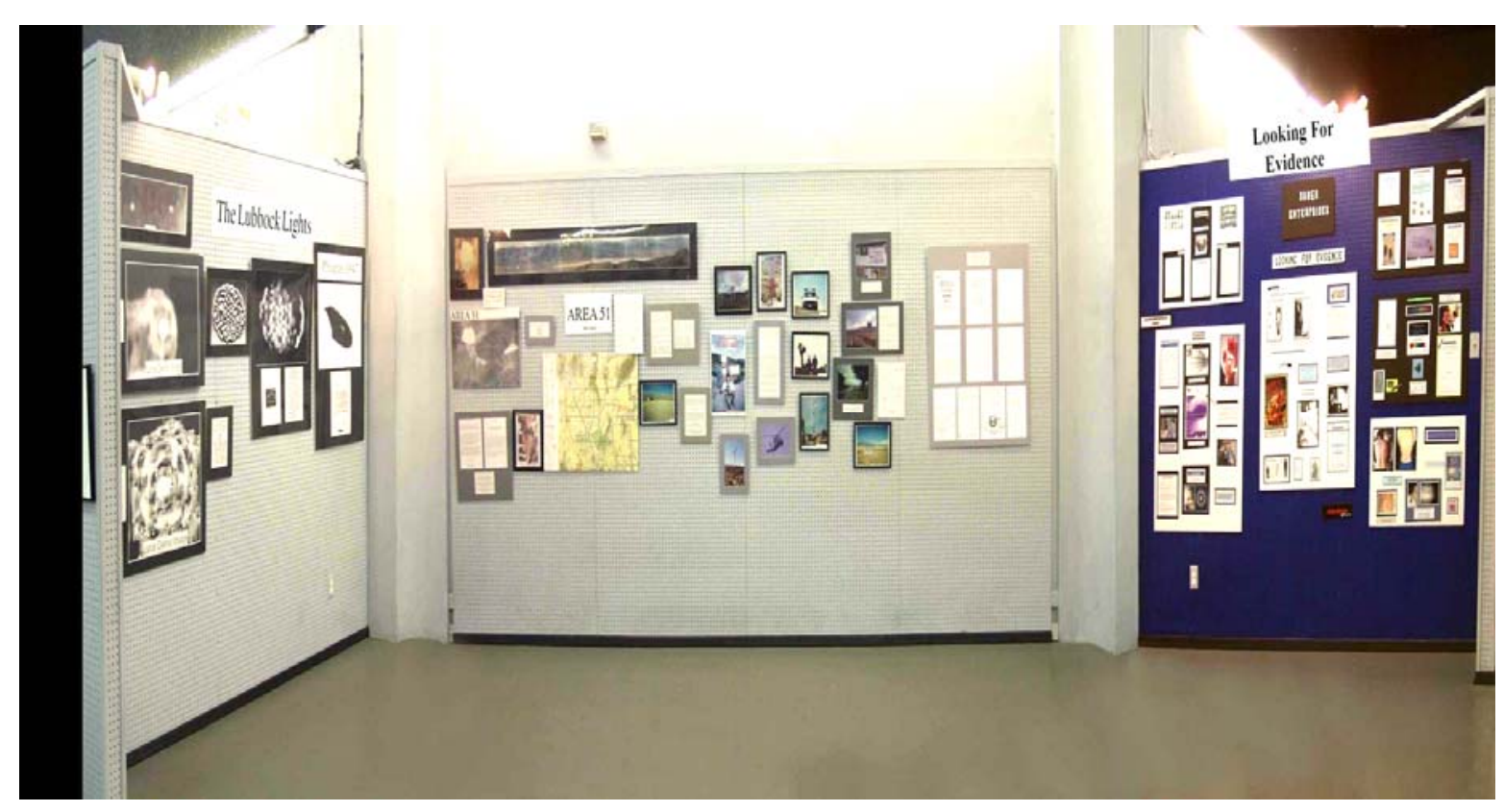

Figura 25 - Exposição de matérias, artigos e curiosidades ufológicas. 


\subsubsection{Círculos Ingleses}

Um fenômeno físico, que ultimamente, vem atraindo cada vez mais a atenção dos ufólogos, e também de turistas, são os círculos em plantações de trigo (e de outros cereais). Estes círculos intrigam a todos pela sua complexidade de desenhos configurados pelo abaixamento ou esmagamento de folhagens das plantações, acreditando que estes possam ser sinais de atividade alienígena.

O que mais impressiona são as dimensões, chegando, por vezes, a atingir cerca de 500 metros de comprimento, parecendo seguir certo padrão. Este fenômeno já foi evidenciado em várias partes do mundo, mas é ao sul da Inglaterra (mais precisamente na área megalítica pré-histórica de Wiltshire, Salesbury, Stonehenge, Silbury Hill e Amesbury) que o fenômeno ocorre com mais freqüência - aparecem às centenas todos os anos, com os mais variados tipos de desenhos e dimensões (Viafanzine, 2005).

Segundo Viafanzine (2005) existem várias teorias que tentam explicar o fenômeno, mas destacamos três:

- A teoria da origem meteorológica: sugere que estes círculos são feitos por ventos circulares.

\section{- A produção por forças naturais manipuladas por uma} inteligência não humana: sugere que efeitos de radiação de alta freqüência encontrados nestas plantações - são capazes de dobrar os talos das plantas. A especulação é com a questão de quem controla estes efeitos, podendo ser humanos (projetos militares) ou supostamente inteligências desconhecidas.

- A hipótese óvni: sendo esta a mais aceita pelos Ingleses. Muitos acreditam que estes símbolos são uma forma de comunicação produzida por uma civilização avançada e desconhecida. Juntamente com esta teoria, há especulações de aparições noturnas de óvnis próximas as regiões.

Com todo este mistério ao redor dos círculos, houve um aparecimento de um novo e lucrativo turismo - no qual muitos fazendeiros cobram taxas para turistas entrarem, visitarem, fotografarem e filmarem os símbolos. 
Muitas pessoas já mencionaram que tiveram algum tipo de reação física (seja positiva ou negativa) durante a visita à formação. Efeitos colaterais que variam de uma simples náusea, dores de cabeça, tontura, dores até zonzeira. Todavia, nem só de plantas é que as características são formadas. Relatos envolvendo pessoas e equipamentos também fazem parte da história dos círculos ingleses. Existem vários relatos sobre o mau funcionamento de equipamentos eletrônicos e de bússolas indo "à loucura" dentro dos círculos. Criou-se, então, um verdadeiro mercado de mistérios, óvnis e, claro, muito dinheiro. Devido a grande demanda, não é raro encontramos fraudes - sendo estas para alguns de fácil reconhecimento uma vez que existem imperfeições grotescas. Seguem abaixo extrações dos site Ufogenesis (1996) de alguns exemplos de tais círculos:
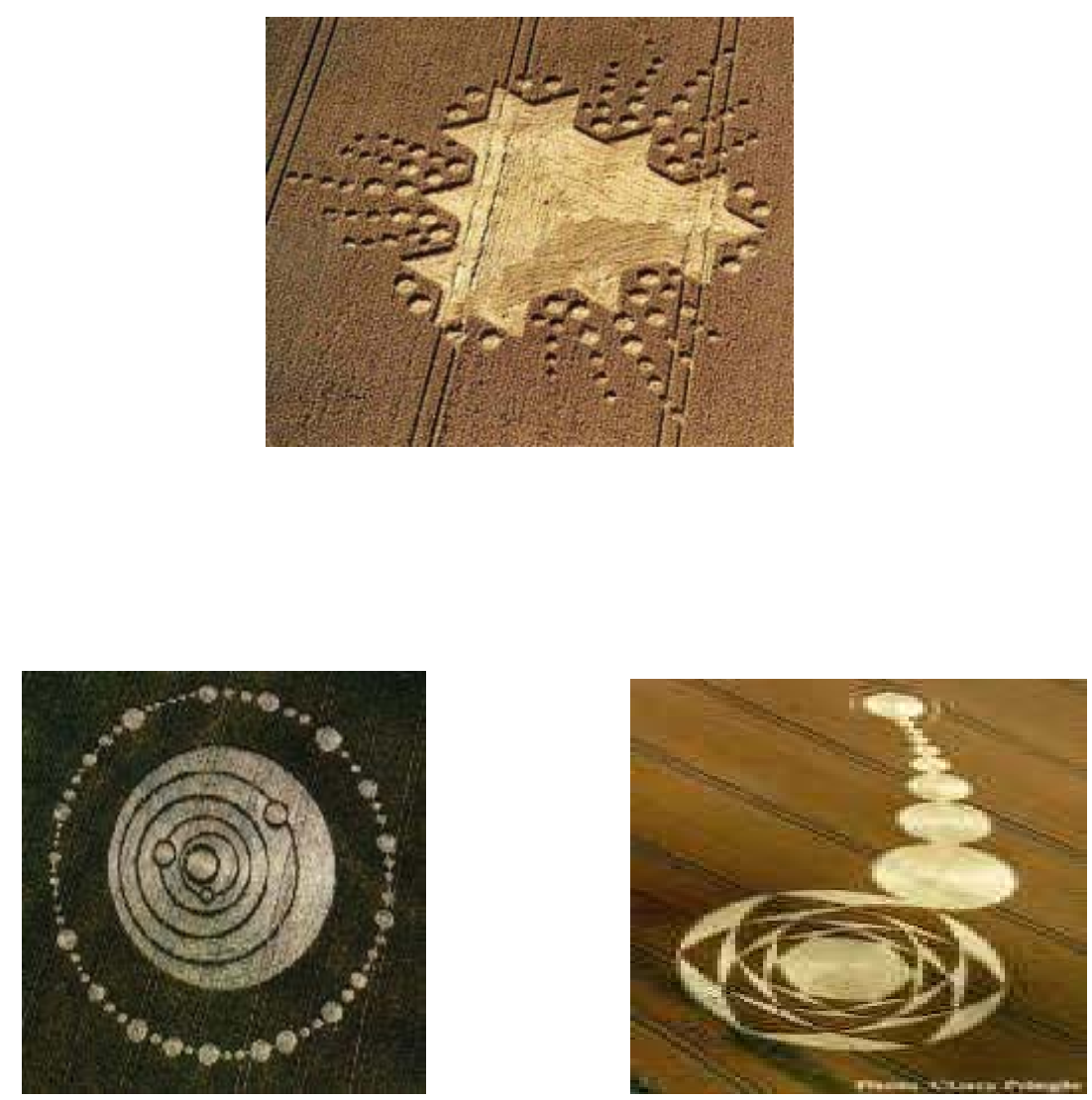

Figuras 26, 27, 28 - Exemplos de alguns círculos observados ao sul da Inglaterra. 

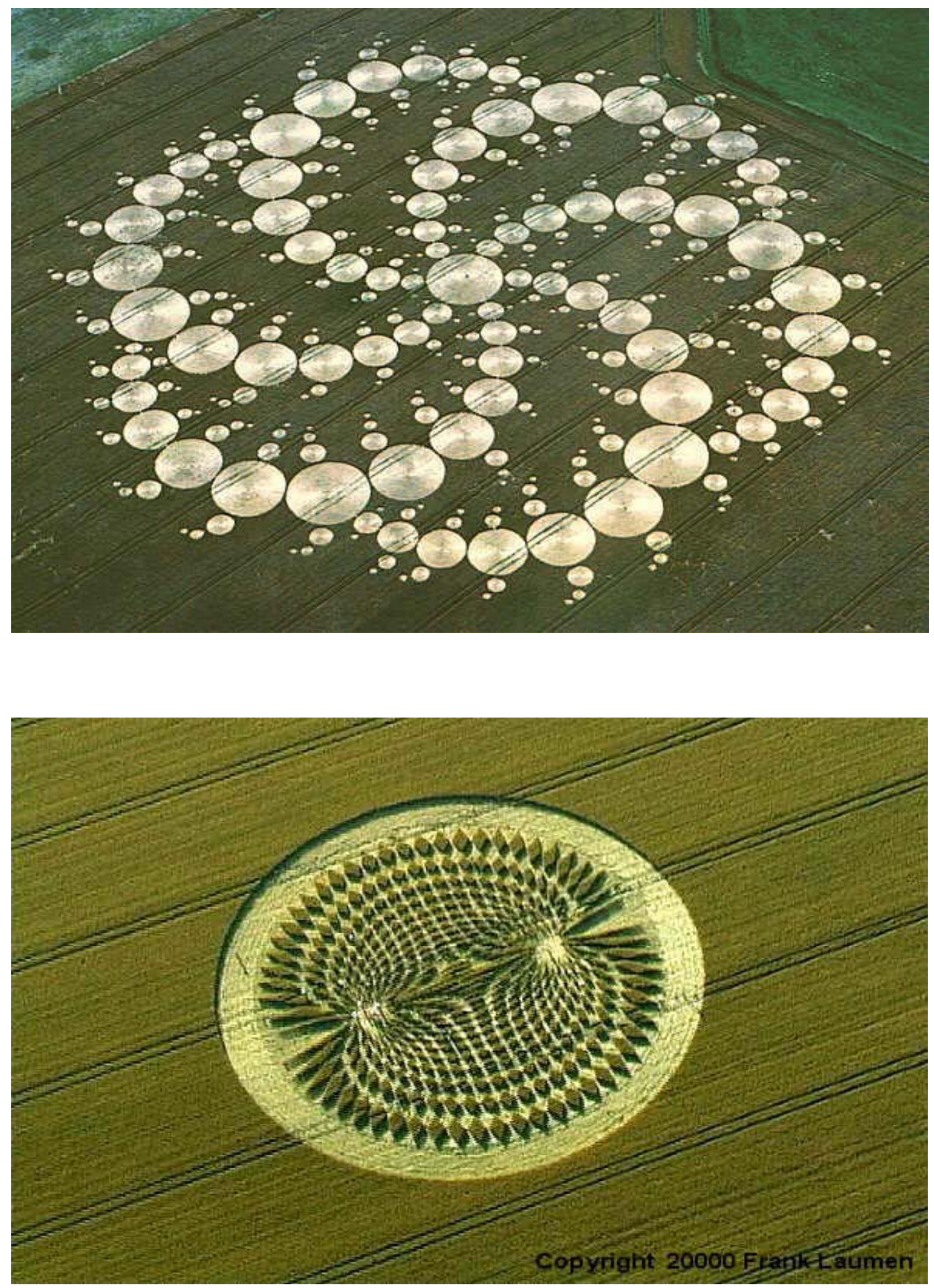

Figuras 30 e 31 - Exemplos de Círculos observados ao sul da Inglaterra. 


\subsection{Nacional}

O turismo ufológico no Brasil tem sido explorado por várias cidades que além de possuírem supostas incidências de avistamentos de ufos, possuem também, belíssimas paisagens naturais, tendo a possibilidade de explorar juntamente com o ufo turismo, outros segmentos como, por exemplo, o ecoturismo e o turismo místico.

\subsubsection{Região Centro-Oeste}

\subsubsection{Parque Nacional da Chapada dos Guimarães - MT}

O parque se localiza numa região central do país, a cerca de $60 \mathrm{~km}$ ao norte de Cuiabá, capital do Mato Grosso. Possui belíssimas paisagens de arenito e cachoeiras, no qual acreditam -se que entre as formações rochosas há pousos de ufos, além inúmeros relatos de aparições destes nos principais paredões naturais da região.

Além das cachoeiras, dos paredões verticais e seus canyons, a chapada também abriga inúmeras cavernas, nas quais já foram encontrados fósseis considerados importantes, além de possuir aproximadamente 50 sítios arqueológicos, onde já foram encontradas pinturas rupestres.

Explorada principalmente pelo ecoturismo, devido a sua peculiaridade natural, é também divulgada como sendo um lugar místico, e como muitos acreditam, reduto de uma energia singular e poderosa, oriunda da belíssima estrutura megalítica da região.

Blecautes que comumente ocorrem na região, clarões no céu, e exóticas formações geológicas (como a misteriosa cidade de pedra - que se trata de efeitos de ações eólicas que formaram uma peculiar paisagem natural rochosa) são utilizadas como forma de atração turística, utilizando o mistério, a exoticidade e por que não a imaginação, como atrativos de uma região com toda a potencialidade de torna-se um dos principais destinos turísticos brasileiros. 


\subsubsection{Serra do Roncador - MT}

A Serra do Roncador, localizada no leste de Mato Grosso, é um lugar com grandes belezas naturais e, ainda pouco explorada pelo homem que colonizou a região em busca, da abundância de diamantes que eram encontrados no passado.

O Roncador é formado por diversos canyons que literalmente roncam com a passagem do vento, chegando a atingir extensões de mais de $800 \mathrm{~km}$, desde Barra do Garças, em Goiás, até a região do Pará.

Vários mistérios circundam esta região. Dentre elas destaca-se a expedição do coronel Fawcet, um inglês que se aventurou pela Serra em meados dos anos 20 atrás de uma civilização perdida. Fawcet nunca mais foi encontrado gerando assim, várias especulações. Muitos acreditam que o coronel teria encontrado a tal civilização através de um portal que se abre em certas ocasiões como, por exemplo, durante o alinhamento de astros, e outros acreditam que Fawcet teria sido morto por índios da região. (Estes que são das tribos Xavantes e Morcegos protegem a Serra contra o homem branco. Para eles a região é considerada sagrada, guardando a sete chaves a suposta entrada do portal).

É uma imensidão solitária e misteriosa no centro da América do sul, à altura do paralelo 15 , que tem atraído a atenção de muitas pessoas pelo seu aspecto místico e exótico. Por conta disso, estão instaladas na região dezesseis representantes de importantes comunidades místicas à procura de contatos e sinais de povos subterrâneos, sobreviventes da suposta desaparecida Atlântida e dos Incas, no Peru. Destaca-se o Monastério Teúrgico do Roncador, que possui rituais secretos, acreditando que na região há o suposto portal para mundos intraterrenos.

De boca em boca, se alastram as histórias de populações subterrâneas, além das supostas visitas de E.T.s e discos voadores. Crenças que convivem harmoniosamente em meio aos cenários de vegetação do cerrado, cachoeiras e trilhas que atraem os turistas.

As estranhas formações rochosas que esta Serra apresenta em muitos pontos ao longo de sua extensão, é acentuada por seus paredões proeminentes 
em meio à selva indevassável. Exemplo disto é a formação rochosa denominada "Dedo de Deus", considerada de forte casuística ufológica.

A Serra possui também sítios arqueológicos ainda pouco explorados por pesquisadores. Um destes lugares é conhecido como a gruta dos pezinhos que possui pegadas datadas de milhões de anos parecidas com humanas, mas possuem 6, 5 e 4 dedos, que, especula-se, serem de Seres Extraterrestre, cuja foto, que pode ser encontrada no site Viafanzine (2005), está exposta abaixo:

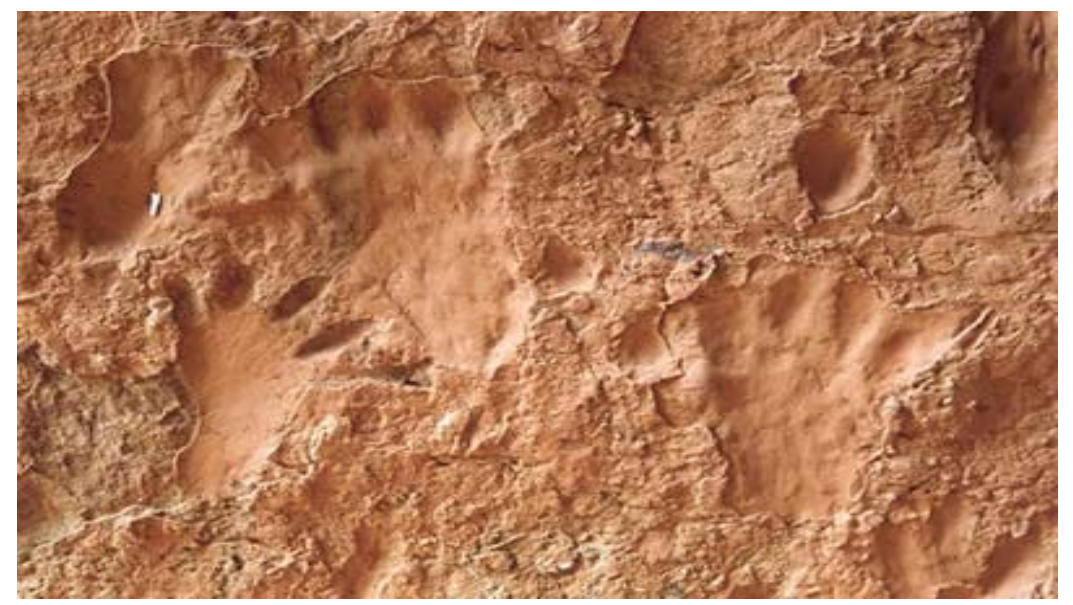

Figura 32 - Gruta dos pezinhos.

Outro lugar considerado sagrado é a "Lagoa Encantada", uma lagoa com total ausência de vida sob as águas. Alguns índios nadam na lagoa, mas não se comprometem a mergulhar muito fundo, pois têm medo de serem sugados e não mais voltarem. Segundo os índios, essa lagoa seria a entrada das moradas dos deuses. Contam que luzes entram e saem da lagoa e vão em direção às estrelas.

Apesar da certeza de alguns, nenhum sinal de presença desconhecida foi detectado pelos radares atentos do Centro Integrado de Defesa Aérea e Controle de Tráfico Aéreo (Cindacta), da Aeronáutica, responsável pelo controle aéreo da região.

A prefeitura de Barra do Garças (MT) visando atrair turistas construiu na cidade o primeiro disco-porto do Brasil. Na verdade, é uma nave feita com chapas de aço toda enfeitada no formato de um disco voador onde as pessoas podem entrar no aparelho e tirar fotos, ou levar uma lembrança fotográfica de um painel de placa galvanizado em forma de extraterrestre, sendo necessário apenas 
colocar a cabeça no buraco do painel para se sentir um verdadeiro ser de outro mundo.

O fato é que a exploração do ufo turismo em Barra do Garças fez com que a cidade ficasse conhecida internacionalmente pela original idéia de se construir um aeroporto para disco voador. Seguem abaixo algumas fotos que ilustram este lucrativo segmento turístico:

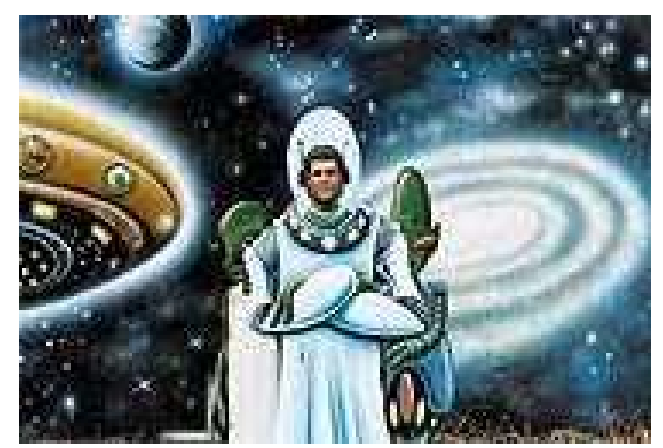

Figura 33 - Foto de turista na atração turística disco porto. 


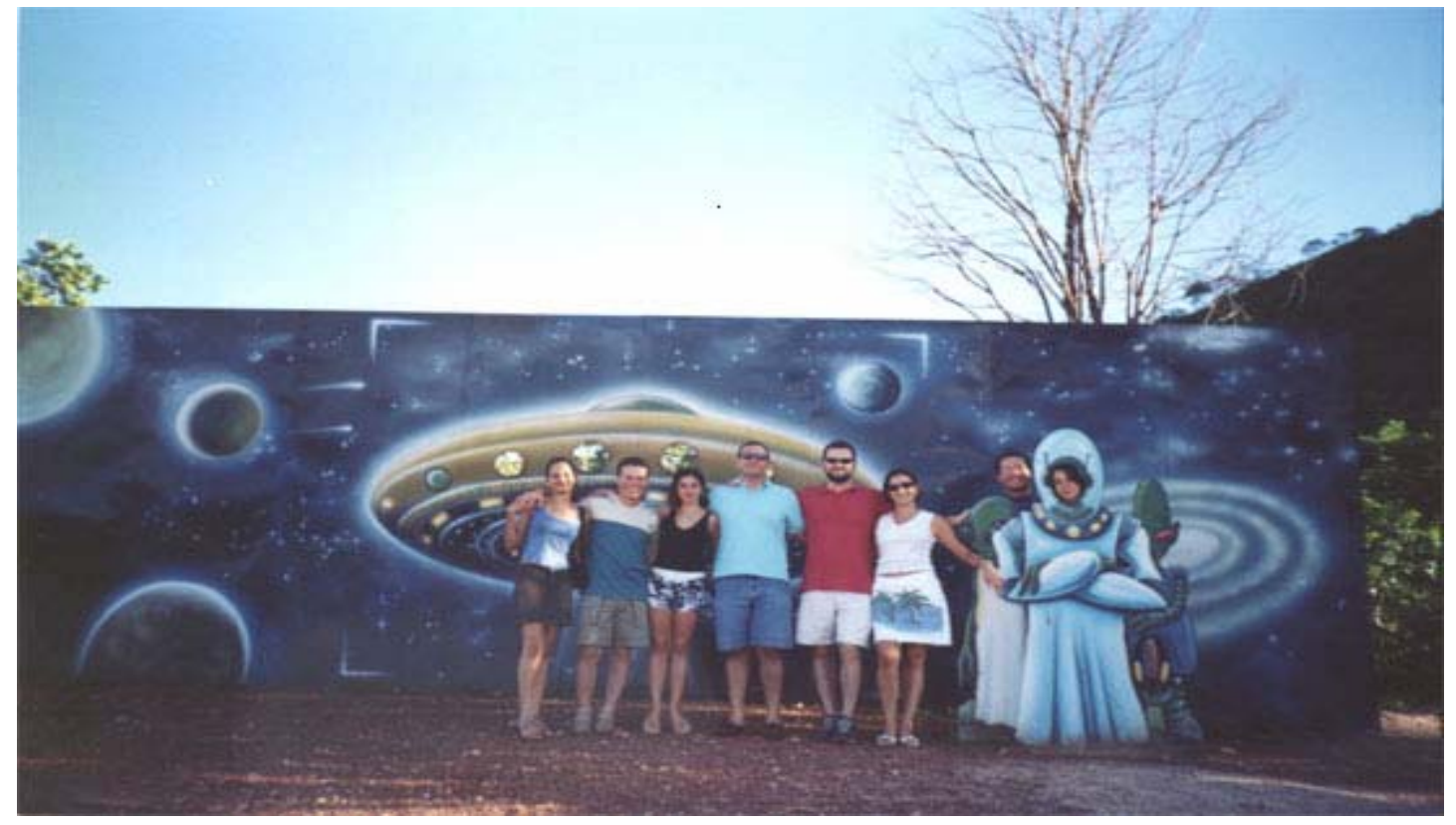

Figura 34 - Atração turística denominada disco-porto.

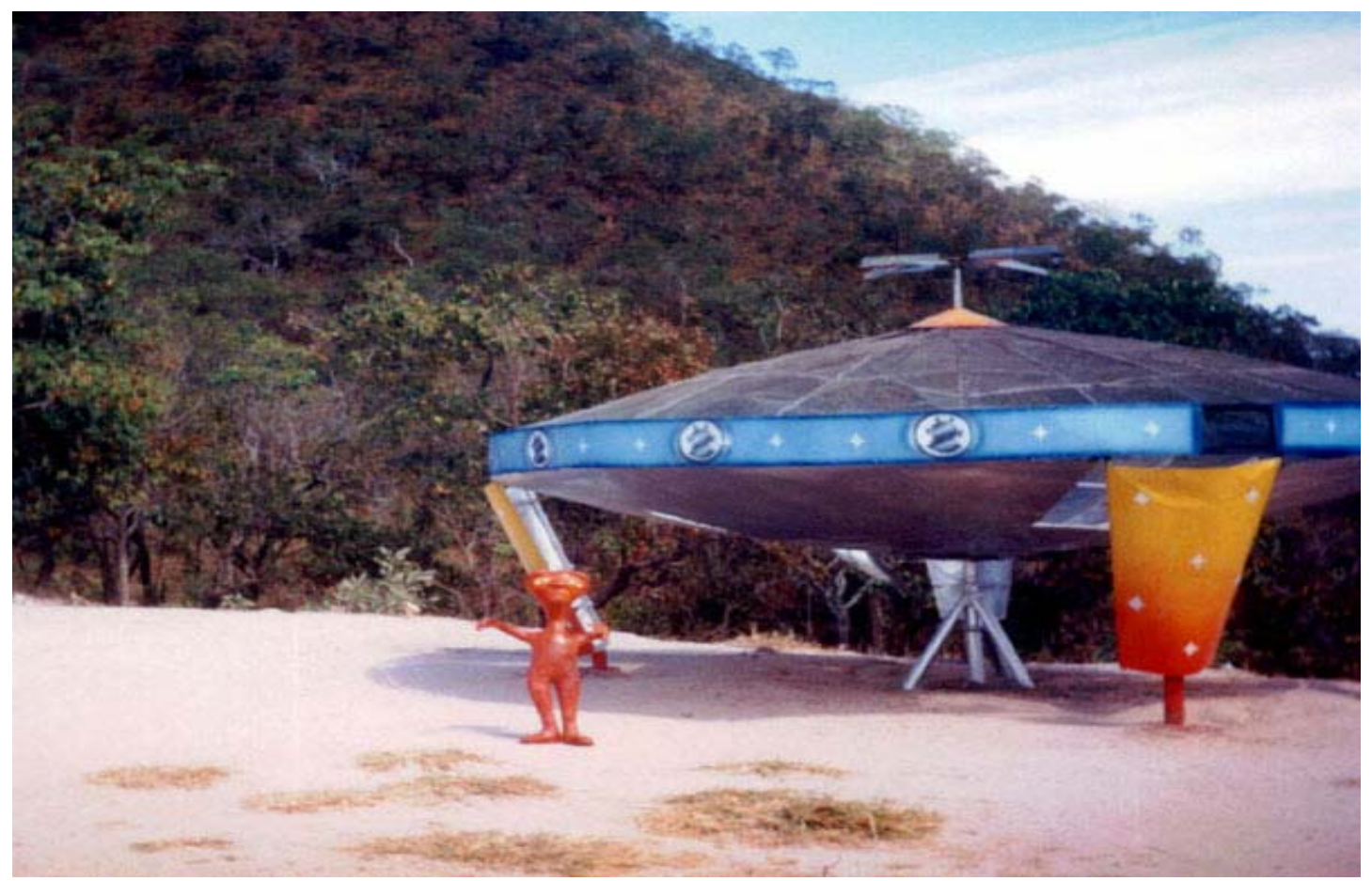

Figura 35 - Atração turística denominada disco-porto. 


\subsubsection{Alto Paraíso - GO}

A cidade de Alto Paraíso encontra-se próxima à região de grande valor ecológico - o Parque Nacional da Chapada dos Veadeiros. Nele as grandes atrações são as várias cachoeiras, canyons e formações rochosas. Em Alto Paraíso já ocorre um turismo direcionado - o turismo místico, em que inúmeros grupos místico-esotéricos se instalaram na cidade, alterando a arquitetura das construções (é comum ver casas com formato de pirâmides ou arredondadas como cúpulas) (Guia Quatro Rodas, 2003).

Há na cidade uma grande centralização das diversas correntes esotéricas, místicas, espirituais e movimentos alternativos em base na crença da suposta atuação de Seres Extraterrestres. Atravessada pelo Paralelo 14, da mesma forma que Machu Pichu, no Peru, proporciona fantásticas histórias sobre discos voadores e Seres Extraterrestres.

A região na qual está situada a cidade de Alto Paraíso de Goiás é considerada por muitos o centro cardíaco do planeta, ou o vórtice energético (chakra) cardíaco da Terra, estando ela localizada sobre uma placa de cristais que, segundo a NASA, é a maior luminosidade vista da órbita da Terra.

Intitulada, também, como sendo a capital do novo milênio, um local predestinado a ser uma espécie de berço do novo homem, ou berço de uma nova raça, ali turistas e moradores passam a noite a observar o céu noturno em busca de óvnis. Nas noites estreladas, ufologistas e místicos vindos de vários continentes, terapeutas e amantes da natureza buscam a energia e o poder de cura dos cristais. Acampados no cume da Serra dos Cristais, ponto de grande convergência de energia, os visitantes vasculham os céus, na esperança de contatos com extraterrestres que, segundo eles, visitam a região.

Outro local de grande visitação turística é o aeroporto da cidade. Na verdade é uma longa pista não acabada, onde mais crédulos visitam esperando receber ali algum contato com discos voadores e extraterrestres. Outros apenas aproveitam a paz e a beleza da vista para meditar e entrar em sintonia com a natureza. 


\subsubsection{Região Nordeste}

\subsubsection{Chapada Diamantina - BA}

A Chapada Diamantina, situada no estado da Bahia possui uma forte tendência ao turismo ufológico e místico. Região com várias cachoeiras, dentre elas a "Cachoeira da Fumaça" - sendo considerada uma das maiores do Brasil, e de inúmeros paredões rochosos, proporciona ao turista paisagens exóticas e exuberantes.

Relatos de observações de moradores e de turistas sobre óvnis são comuns na região. Dentre eles destaca-se nas proximidades de grutas do parque. Dentro destas cavernas como a "Gruta do Poço Encantado", em certa época do ano, a luz que penetra por uma fenda mergulha até as profundezas do lago com águas cristalinas criando um maravilhoso efeito visual no ambiente.

Sentir uma presença sobrenatural faz parte do mistério que muitas pessoas atribuem à Chapada. Principalmente quando se fala do morro São Jerônimo, um platô situado acerca de 1.000 metros de altitude, considerado pelos estudiosos como o mais belo ufo-porto (aeroporto natural de óvnis, muitas vezes em locais altos como vales ou montanhas) do Brasil. $\mathrm{O}$ acesso ao topo reserva muitos percalços aos aventureiros - difíceis degraus de pedras, subidas íngremes, quase em inclinação de 90 graus. Quase sempre, quem se arrisca a passar uma noite ao relento no alto do morro, sob as estrelas e ao ar frio, volta com algum acontecimento extraordinário guardado na memória.

A própria história da Chapada Diamantina está associada, também, à exploração de ouro e diamante. Considerada durante muito tempo a maior produtora mundial de diamantes, ainda é possível encontrar na região garimpeiros à procura de pedras preciosas.

Turismo, supostos óvnis, e beleza natural vivem em harmonia em um dos principais roteiros turísticos brasileiros. 


\subsubsection{Parque Serra da Capivara - PI}

Ao sul do estado do Piauí, em plena caatinga, encontra-se o Parque Nacional da Serra da Capivara. Segundo Viafanzine (2005) é o lugar mais rico do nosso continente em pinturas rupestres, uma vez que seu "acervo" inclui uma infinidade de pinturas distribuídas por cerca de 450 sítios arqueológicos.

Declarado patrimônio cultural da humanidade pela Unesco e administrado pela Fundação Museu do Homem Americano - Fumdham, de caráter privado, em parceria com o Ibama - Instituto Brasileiro do Meio Ambiente e dos Recursos Naturais Renováveis, é um exemplo de conservação, pesquisa e respeito ao meio ambiente em pleno sertão nordestino.

Datadas em torno de 10 mil anos, muitas destas pinturas retratam supostos "seres" de outro mundo. Cabeças avantajadas, antenas, corpos delgados, e algumas inscrições em pedras são alguns exemplos destes mistérios da região.

O cartão postal do parque é a chamada "Pedra Furada" - o qual é um belo paredão rochoso com dezenas de metros de altura, possuindo um enorme "furo" no meio. Nas proximidades desta formação foram encontrados os vestígios mais antigos da presença do homem nas Américas, com idade aproximada de 50 mil anos. Guias conduzem o visitante a caminhos repletos de sinais e vestígios de civilizações pré-históricas que deixaram evidências de que viveram ali 50 mil anos, contrariando a arqueologia ortodoxa sobre a chegada dos primeiros habitantes às Américas, que teria ocorrido há "apenas" 12 mil anos.

O Parque se presta à prática do turismo ecológico e cultural, mas devido a algumas peculiaridades de pinturas rupestres está sendo vinculado ao ufo turismo. Os inúmeros sítios arqueológicos já descobertos permitem oferecer ao visitante uma gama variada de circuitos e visitas. Seguem abaixo alguns exemplos de figuras rupestres que podem ser encontradas em tais sítios, sendo todas extraídas do site Gepuc (2000): 


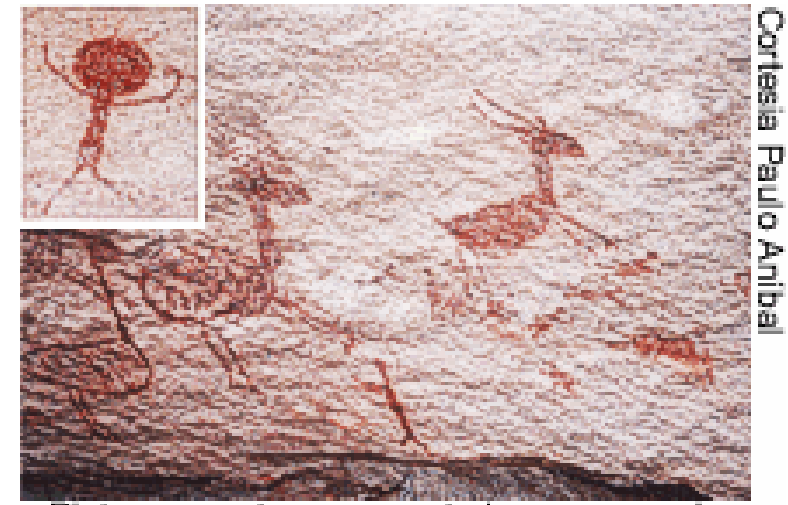

Pintura rupestre representado uma cena de

caça. No detalhe, ser de cabeça

desproporcional e estatura reduzida

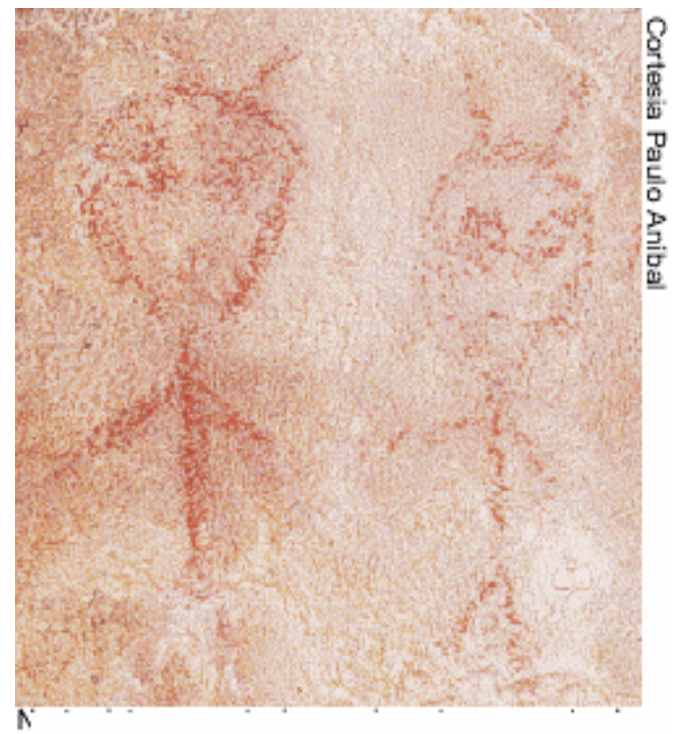

Figuras 36 e 37 - Pinturas encontradas no Sítio do Boqueirão da Pedra Furada - Piauí (Parque Nacional da Serra da Capivara), datadas de 50.000 anos atrás.

\subsubsection{Município de Ingá - PB}

No município de Ingá, distante cerca de 100 km de João Pessoa, encontrase o primeiro monumento arqueológico tombado como patrimônio nacional em 1944 (Viafanzine, 2005).

Seu terreno está coberto por mais de 500 sítios arqueólogos catalogados, e trazem esculpidos nelas uma centena de inscrições em baixo - relevo, deixando livre o imaginário de turistas e pesquisadores. 
Possuindo 24 metros de comprimento por 3,8 metros de altura tomados por inscrições de quase 10 mil anos, as condições do sítio são precárias onde a erosão e agressões de visitantes já destruíram parte das relíquias.

A arqueologia tem um nome bem específico para definir as inscrições que existem no sítio de Ingá: Itacoatiara. Quer dizer "inscrições em pedra nas margens de um rio" - ou seja, o Rio Ingá.

Pesquisadores ao analisarem os detalhes da Pedra do Ingá, puderam constatar estranhas figuras que se assemelham a astros, a animais, a objetos desconhecidos, e até a algo que lembra um foguete. Existem, ainda, inscrições sobre a posição de constelações, contagem do ano solar e lunar, e velocidade da órbita terrestre.

Uns atribuem às inscrições à passagem dos fenícios pela América, e outros aos índios Cariri, que lá habitavam, mas esta teoria foi descartada, uma vez que estes desconheciam os metais ou qualquer outro instrumento capaz de produzir sulcos perfeitos e polidos nas rochas.

A principal infra-estrutura turística encontra-se em Campina Grande - à 46 km do sítio arqueológico. Apesar de Campina Grande ser mundialmente conhecida pelas suas festas juninas, o município de Ingá vem atraindo um público voltado para o mistério e o misticismo. Seguem abaixo algumas fotos ilustrativas extraídas de Ufo (2004): 

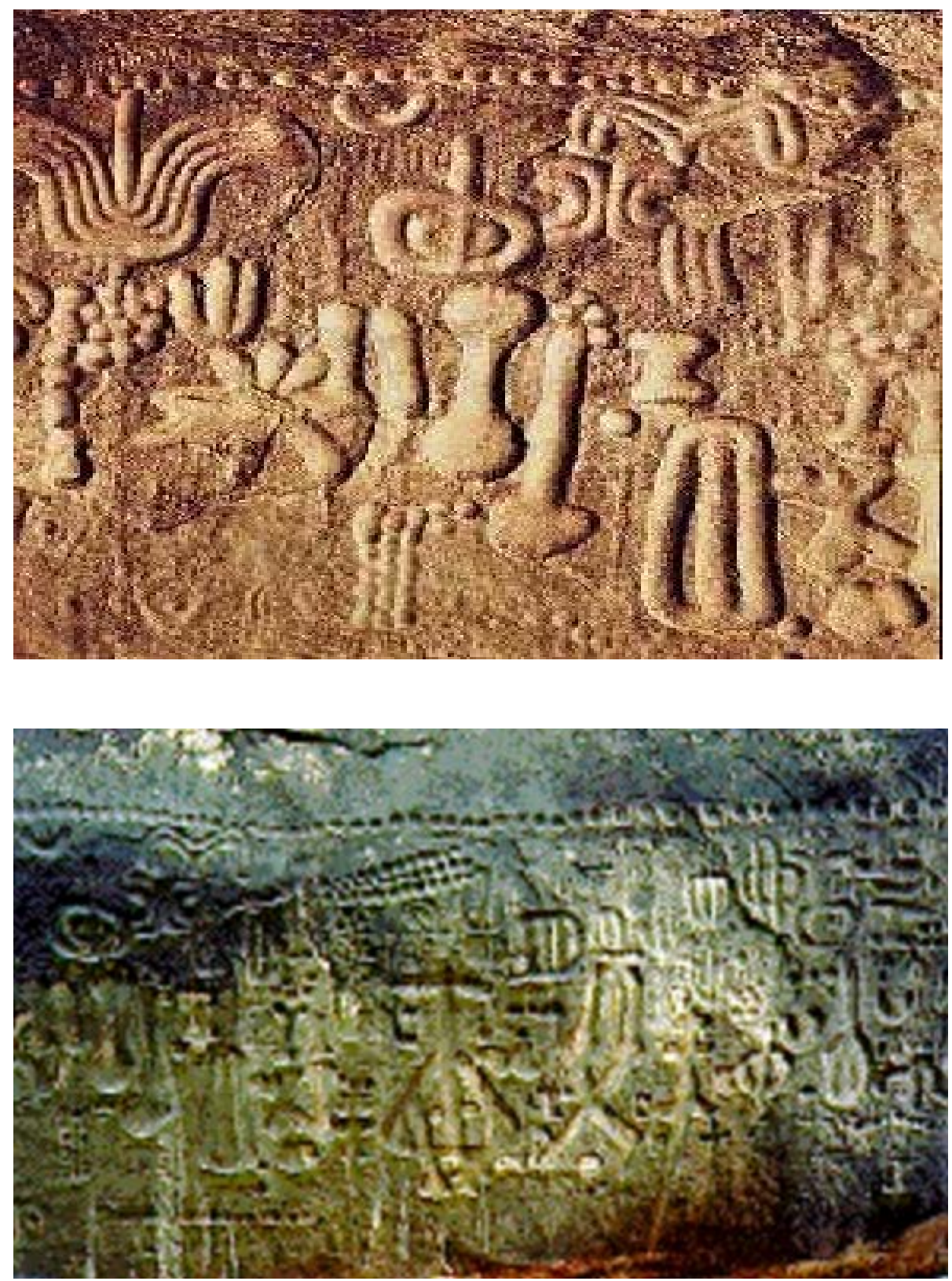

Figuras 38 e 39 - Inscrições rupestres vinculadas à astronomia encontradas na Pedra do Ingá.

\subsubsection{Região Norte}

A Região Norte é a maior das regiões brasileiras e abriga a gigantesca Floresta Amazônica. Formada pelos estados do Amazonas, Pará, Acre, Rondônia, Tocantins, Amapá e Roraima, a região é habitada por comunidades indígenas, caboclas, ribeirinhas, extrativistas e negras remanescentes de quilombos, além das populações que vivem nas cidades. 
Por ser uma das últimas grandes reservas de recursos naturais - são 3,3 milhões de quilômetros quadrados, só no Brasil - e o local mais rico em biodiversidade do planeta, a Amazônia tem uma vocação natural para o Ecoturismo, atraindo pessoas de todo o mundo.

Assim, o ecoturismo com os seus hotéis de selva, cavernas e trilhas na floresta, o turismo de pesca, as belíssimas praias fluviais, e os seus carnavais (tais como da cidade de Parintins - festa do boi - bumbá), são os principais atrativos explorados na região.

Nos anos 70, a região amazônica ficou conhecida pela sua forte casuística ufológica devido à investigação do governo sobre a presença de supostos discos voadores na região. Intitulada de Operação Prato, como já referida anteriormente, até os dias de hoje ainda é lembrada pela ocorrência daquela época.

Pesquisando o folclore brasileiro - e em particular o da Amazônia muitos "fantasmas" e "assombrações" descritos por indígenas e caboclos são para muitos ufólogos avistamentos de supostas naves tripuladas, sondas teleguiadas e seres extraterrestres. Acredita-se que a atuação de naves sobre a floresta remonte há séculos, quando nativos de diversas nações indígenas viam estranhos seres descendo do céu e os identificavam através de lendas mitológicas que se perpetuariam por inúmeras gerações.

Apesar da grande potencialidade da região para o turismo ufológico (uma vez que entre os ufólogos a região amazônica é uns dos lugares em que supostamente mais aparecem óvnis no Brasil), a região ainda não explora turisticamente este tipo de segmento.

Segue abaixo, então, alguns lugares da região norte que possuem todo um potencial para a exploração do turismo ufológico. 


\subsubsection{Cidade de Alenquer - PA}

Em uma área de imensas e belas cachoeiras da região Amazônica, no interior do estado do Pará, esconde-se uma pequena cidade chamada Alenquer, também conhecida como a Cidade de Pedra ou Cidade dos Deuses Amazônicos. A cidade é repleta de grutas, capelas, colunas e diversas formações rochosas.

Nesta localidade viveram os primeiros povos da Amazônia. Com inscrições em sítios arqueológicos que datam de mais de 11.000 anos, deixaram registrados nas pedras pinturas rupestres que estão espalhadas por toda as regiões, muitas ainda, não estudadas e catalogadas.

A cidade dos deuses é uma área de campo de difícil acesso dentro da floresta Amazônica. Tem uma vegetação rasteira, e facilmente os visitantes encontram uma flora (tais como cactos) que não são comuns na Amazônia.

As formas rochosas nesta região atingem 5 metros de altura no qual encontram-se inscrições que parecem representar a passagem de uma suposta civilização muito primitiva, além se um suposto calendário, que nos fazem refletir em como uma civilização antiga tinha acesso à contagem do tempo.

\subsubsection{Cidade de Monte Alegre - PA}

Na cidade de Monte Alegre no estado do Pará, em plena selva amazônica, foram encontrados inúmeros sítios arqueológicos datados de 12 mil anos. O que intriga os cientistas é de que além de esta extinta civilização ser mais antiga do que os dos povos Maias e Incas, suas inscrições assemelham-se com naves espaciais, e até de representações de supostos astronautas alienígenas (com antenas e rostos semi-humanos) e de astros tais como a lua, o sol e os planetas.

O maior sítio arqueológico de Monte Alegre fica na Serra do Paituna, onde existem várias cavernas e inúmeros painéis de pinturas rupestres. Na caverna chamada de Pedra Pintada os arqueólogos encontraram resquícios humanos desta antiga civilização.

Outros atrativos estão nos arredores da cidade, como cachoeiras e trilhas, podendo ser explorado, também, o ecoturismo. 


\subsubsection{Ilha de Marajó - PA}

A Ilha do Marajó, na foz do rio Amazonas, é o maior arquipélago fluvial do mundo, com aproximadamente 50.000 km2, formado por três ilhas: Mexiana, Ilha Grande de Gurupá e Caviana, um dos pontos mais atingidos pela violência da pororoca. Constituiu-se historicamente em importante base do desenvolvimento estadual, contribuindo desde o século XVII com sua produção de carne e couro de gado, pescado, produtos artesanais e essências florestais nativas, detendo um grande potencial turístico no segmento rural, com uma demanda espontânea de diversas origens.

A llha do Marajó, na foz Rio Amazonas, é das primeiras referências quando se fala do estado do Pará. É a maior ilha fluvio-marinha do mundo, considerada um dos principais pólos ecoturísticos da Amazônia. Dividida em 16 municípios, esse pedaço da Amazônia, privilegiado, representa o portão da entrada do turismo paraense.

Devido a grande incidência de supostos avistamentos de ufos, coloca-se a região como um grande potencial para o turismo ufológico, além do que a localidade é repleta de lendas que os ufólogos interpretam como sendo óvnis onde muitas vezes emitem feixos de luz sobre a água, e até supostamente perseguem moradores da região.

\subsubsection{São Gabriel da Cachoeira - AM}

Perto do município de São Gabriel da Cachoeira, estado do Amazonas, encontra-se o Pico da Neblina - sendo considerado o ponto mais alto do Brasil, com 3014 metros, possuindo uma área de aproximadamente 2.200.000 ha. Atualmente os transportes fluvial e aéreo são as opções para se chegar até o Parque.

O Parque Nacional do Pico da Neblina é o segundo maior Parque brasileiro e o terceiro de toda a América Latina. Também se encontra em seus limites a segunda maior elevação do País, o Pico 31 de Março, com 2.992 m. A vegetação da área compreende diversas formações e abriga uma das faunas mais ricas do país, com várias espécies ameaçadas de extinção. 
São Gabriel da Cachoeira é considerada ponto de apoio aos visitantes que desejam conhecer o Pico da Neblina; mas a cidade ainda não está completamente estruturada para receber um grande número de turistas. As acomodações são simples e em número reduzido.

Destaca-se este município como um grande potencial ao turismo ufológico, uma vez que a região é repleta de mistérios e lendas que fazem o imaginário dos visitantes e moradores serem nada convencionais.

Para começar, próximo ao Parque encontra-se o Morro dos Seis Lagos, onde cada lago contém uma cor diferente, por motivos desconhecidos.

Um outro mistério que circunda a região são as inscrições feitas em lajedos, à beira do rio Negro. Segundo Villarruba (1997), estas inscrições seriam vários círculos com diâmetros que variam de 10 a 30 cm, com sulcos profundos, perfeitamente talhados e polidos, dispostos em feixes em forma de leque.

Encontram-se espalhadas sempre ao longo do rio Negro e de outros rios afluentes daquela região amazônica. Sem qualquer explicação satisfatória os moradores da região esperam até hoje estudos que comprovem a autoria de tais inscrições. Sinais semelhantes existem na Europa, Ásia e África, mas também, sem uma explicação concreta de tais fenômenos.

E um outro fato que gerou bastante polêmica nos anos 70 , foi quando o pesquisador Roldão Pires Brandão anunciou a descoberta de pirâmides próxima à região de São Gabriel da Cachoeira. Ele atribuía estas pirâmides a uma civilização pré-incaica, ou mesmo Atlante (Villarruba, 1997).

O fato é que se criou toda uma lenda em torno de cidades perdidas no meio da selva amazônica, com pirâmides encobertas pela densa mata, e, claro, de óvnis que supostamente estariam na região para coleta de nossa flora e fauna. 
Ninguém até o momento encontrou as tais pirâmides, mas alguns pesquisadores afirmam que já houve denúncias de bloqueios de estradas em determinados horários por militares americanos na região da suposta localidade das pirâmides.

\subsubsection{Região Sul}

\subsubsection{Itaara-RS}

A cidade de Itaara localizada na região central do Rio Grande do Sul possui 4.500 habitantes e disputa com a cidade mineira de Varginha o título de capital brasileira de ufologia (Fenômeno, 2000).

Deve-se a nomeação ao título por ser um dos escassos museus ufológicos no Brasil. O museu possui um observatório com telescópios, um acervo de trezentas fitas com supostos óvnis, três mil fotografias, uma biblioteca com novecentos livros sobre fenômenos ufológicos, e claro réplicas de E.T.S espalhados por todo o seu interior.

Inaugurado em junho de 2001, o museu integra o projeto The Search for Extraterrestrial Intelligence, vinculado a Nasa - agência espacial Norte Americana.

Apesar de haver tido algumas resistências na comunidade para a implantação do museu, hoje muitos moradores estimulam o turismo na região e acham que o lugar é adequado, uma vez que acreditam que a área possui uma energia especial capaz de atrair seres espaciais.

Pelo fato do museu estar inserido em uma cidade pequena e tranqüila, longe da badalação das grandes cidades, ufólogos encaram o projeto de uma forma séria e sem desdém, pois muitos acreditam que teriam se fosse nas grandes cidades.

\subsubsection{Município de Garuva - SC}

O município de Garuva - próximo a Joinville, localizado no estado de Santa Catarina é um grande potencial ao turismo ufológico. Localizada na base da Serra 
do Mar, tem a maior parte de seus 432 quilômetros quadrados de área ocupada por extensas florestas da Mata Atlântica, sendo hoje explorado pelo ecoturismo.

Nesta região, se localiza o ponto turístico do morro Monte Crista. Este local é repleto de mistérios e lendas de ufos que abrigam a localidade. Para se chegar ao topo do morro é necessária uma caminhada de 5 horas dentro da Mata Atlântica, por escadarias feitas pelos Jesuítas no século XVIII. Devido à longa caminhada deve-se acampar no topo, onde está o principal atrativo do passeio devido à localização remota do local. Do alto se tem uma visão parcial da cidade de Joinville e parte do litoral Catarinense e Paranaense. As pedras enormes ali existentes mexem com a imaginação de todos pelas formas que parecem terem sido esculpidas, além da esperança de alguns curiosos visualizarem possíveis luzes estranhas no céu estrelado da região.

Segundo SC (2002) apud Dr. Raymond Bernard,

“(...) há nos confins subterrâneos do planeta uma verdadeira base de discos voadores, cujas entradas são aberturas nos pólos e em alguns outros pontos da terra, entre eles as imediações no Monte Crista na região de Joinville. Segundo Dr. Bernard, no fundo da terra vive uma super-raça que não deseja manter contato com o homem, mas foi obrigada a lançar seus objetos voadores quando o planeta foi ameaçado pela tecnologia nuclear".

\subsubsection{Região Sudeste}

\subsubsection{Cidade de Varginha - MG}

Ao sul do estado de Minas gerais encontra-se a cidade de Varginha. Ela é a cidade brasileira mais famosa entre os ufólogos e de pessoas que acreditam em óvnis e vidas extraterrestres.

Até o começo dos anos 90, a cidade vivia da exportação de café e era anônima como muitas cidades pequenas do território brasileiro. Em 1996, com a super exposição da mídia com a suposta aparição de seres de outro planeta que teriam sido vistos por três meninas, a cidade ficou mundialmente conhecida como a "Cidade dos E.T.s" (Revistagalileu, 2005).

Inicialmente a história do aparecimento de supostos E.T.s foi renegada pelos moradores da região, mas depois de poucos anos, a cidade explora 
assiduamente o turismo ufológico. Na verdade, é a região brasileira que mais utiliza este tipo de turismo como forma de sobrevivência econômica, se igualando para muitos ao caso da cidade de Roswell - Estados Unidos, que arrecada milhões de dólares anualmente com histórias de E.T.s, óvnis e museus ufológicos.

Enxergando a possibilidade de lucrar com o tal incidente ocorrido em 1996, o trade turístico criou uma infra-estrutura completa, com bares e restaurantes temáticos, parques, monumentos que são replicas de naves espaciais, e até excursões e pacotes turísticos onde o turista além de conhecer os "supostos lugares místicos" e belezas naturais da região, também tem a possibilidade de ser levado até ao local onde supostamente aconteceu o famoso caso de Varginha.

Um dos principais pontos turísticos de Varginha é um reservatório em formato de nave espacial instalado na Praça Rio Branco, que vem atraindo um grande número de turistas.

Alguns restaurantes possuem cadeiras em formato de E.T.s, e contam com cardápios temáticos - tais como "salmão lunar na chapa", ou "frango E.T. varginhense".

Mesmo sendo comparada a cidade de Roswell, para muitos ufólogos a cidade ainda reflete o descrédito da pesquisa ufológica no Brasil. As atitudes tomadas pelos americanos não se comparam a um terço promovido pela cidade de Varginha. Para eles, se estas atitudes fossem desenvolvidas tais como a cidade americana, Varginha geraria mais capital, estimularia a iniciação científica perante os jovens, e ativaria a ufologia para ser pesquisada com seriedade. Seguem algumas fotos extraídas de Ufo (2004), que ilustram a exploração do ufoturismo na cidade de Varginha: 


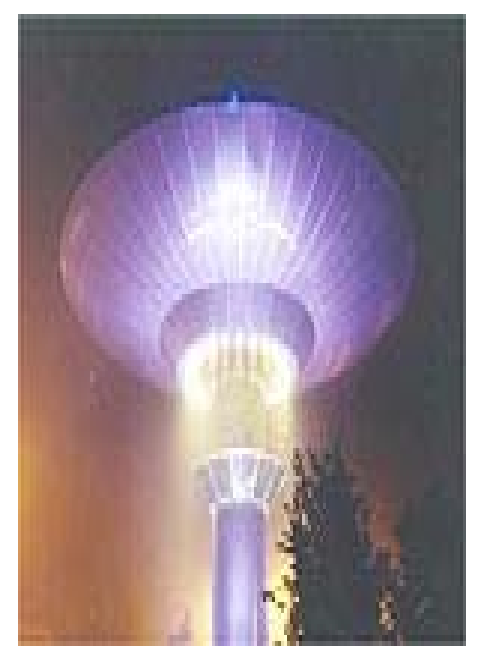

Figura 40 - reservatório de água instalado no centro da cidade de Varginha com inferência a um disco voador.

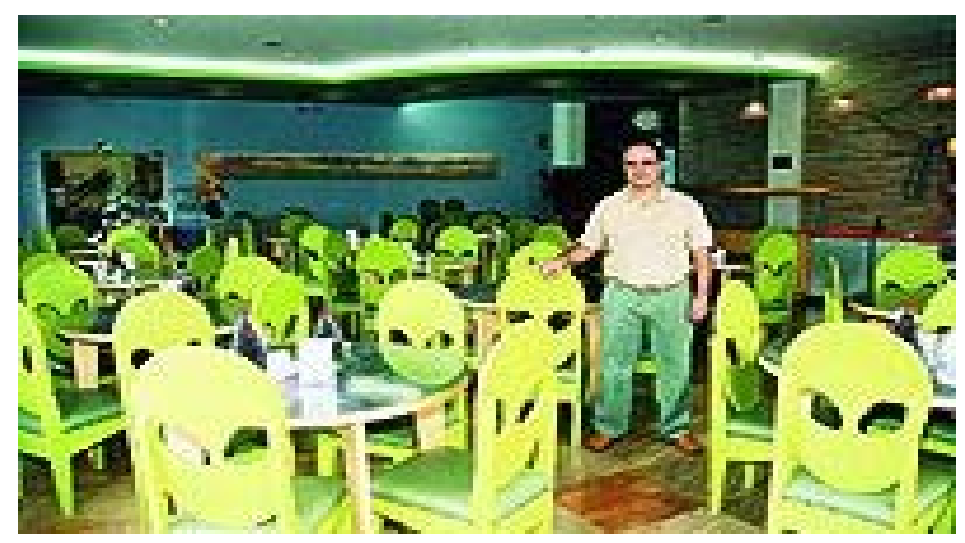

Figura 41 - Restaurante temático em Varginha.

\subsubsection{São Thomé das Letras - MG}

A região sul do Estado de Minas Gerais é um dos locais com grande índice de supostas aparições de ufos no território brasileiro. Destaca-se a cidade de São Thomé das Letras, incrustada numa área montanhosa a mais de 1400 metros de altitude, envolta por inúmeras lendas e mistérios.

São Thomé das Letras é uma cidade rústica, edificada sobre uma montanha de pedras - as mesmas utilizadas na construção de casas e no calçamento das ruas. Isso dá razão a um dos nomes pelos quais é conhecida: "Cidade das Pedras". 
Acredita-se que São Thomé seja um dos sete pontos energéticos da Terra, possuindo uma ligação subterrânea até Machu Pichu, o que atrai para o lugar místicos, sociedades espiritualistas, científicas e alternativas de todo Brasil.

A origem da cidade está cercada de misticismo, desde o seu surgimento, inclusive a do seu nome. No Século XVII, um escravo em fuga teria encontrado uma imagem de São Tomé dentro de uma gruta. Sendo capturado pelo seu senhor e recolhendo, também, a tal imagem. Dias depois a imagem teria reaparecido no interior da mesma gruta sendo considerado milagre para toda a população.

Em São Thomé das Letras encontram-se inúmeras pessoas relatando histórias relacionadas aos supostos discos voadores e seres intraterrenos. E, com isso, o turismo da região vem se desenvolvendo assiduamente.

Entre as principais atrações estão algumas cachoeiras, desenvolvendo juntamente o ecoturismo, além de algumas cavernas, sendo estas denominadas de "Gruta do Carimbado" - que segundo alguns possui uma ligação subterrânea até Machu Pichu, e uma outra chamada de "Gruta da Bruxa" - onde muitos acreditam em costumeiras aparições de ufos.

Um outro ponto bastante visitado é uma construção semi-acabada de uma pirâmide. Localizada em um ponto elevado da cidade, ela é "disputada" pelos moradores e turistas que vão em busca de visualização de luzes estranhas no céu.

\subsubsection{Peruíbe - SP}

O litoral sul do estado de São Paulo, principalmente na região de Peruíbe, é mais uma das áreas com grande incidência de observações de supostos ufos.

Situada geograficamente entre duas grandes localidades de preservação ambiental da Mata Atlântica - a estação ecológica da Juréia - Itatins e o Parque Estadual da Serra do Mar, a cidade é conhecida não só por suas belezas naturais, mas também pelos estudos ufológicos promovidos por grupos de ufologia da região. 
São descritos pela população supostos objetos luminosos diurnos e noturnos, fazendo com que o município percebesse o grande potencial ao turismo ufológico, promovendo todos os anos encontros com temáticas relacionadas a este tema.

Até mesmo no guia turístico da cidade do ano de 2004, saíram cinco páginas destinadas a divulgação de pesquisas ufológicas realizadas na região. No mesmo ano, a própria prefeitura da cidade lançou um roteiro turístico, onde constam certas localidades turísticas com forte casuística ufológica a serem visitadas (Ufo, 2004).

\subsubsection{Conservatória-RJ}

A cidade de conservatória, localizada no interior do estado do Rio de Janeiro é nacionalmente conhecida como a Terra da Seresta, um movimento musical singular mantido há décadas por artistas locais, que atrai centenas de turistas todos os finais de semana.

Lugar de alta casuística ufológica, os moradores da cidade convivem com estes supostos mistérios de forma natural e hilária, uma vez que já possuem mais de cinqüenta canções em que discos voadores e alienígenas são mencionados no repertório das serestas (Ufo, 2004).

Segundo Ufo (2004) é, também, palco de grandes belezas naturais, dentre o qual destaca - se o da Serra da Beleza, um dos lugares que segundo os moradores é de maior intensidade em observações de ufos no país.

Ufólogos e moradores da região tentam a implementação do ufo turismo da região, contando com o apoio da TurisRio - companhia de turismo do estado do Rio de Janeiro. Pretendem transformar Conservatória e a Serra da Beleza em centros de referência para a ufologia brasileira.

Placas de sinalizações com denotações ufológicas, eventos, congressos, e vigílias noturnas com respectivos guias turísticos na região da Serra da Beleza são as principais atrações da cidade. 


\subsubsection{Outras Regiões}

Para finalizar, cabe ressaltarmos que, embora no presente trabalho não tenhamos mencionado algumas cidades que exploram ou tenha potencial turístico ao objeto em questão, em função da escassa literatura acerca da temática, podem-se citar, também, as seguintes localidades:

- $\quad$ Analândia - interior de SP;

- $\quad$ Botucatu - interior de SP;

- $\quad$ Cordilheira do Espinhaço - MG;

- $\quad$ Mombuca - SP;

- $\quad$ Niterói - RJ;

- $\quad$ Serra dos Galés, Paraúna - Go;

- $\quad$ Visconde de Mauá - RJ. 


\section{Considerações finais}

Uma vez concluído o referencial teórico, bem como re-analisadas e interpretadas as informações acerca do objeto, resgata-se a pergunta chave da presente pesquisa: o turismo como fonte de geração de renda e representante de manifestações culturais e históricas, está se apropriando do conhecimento oriundo da ufologia na tentativa de criar um novo segmento turístico?

Nossa conclusão final é a de que os dados oriundos da pesquisa bibliográfica podem confirmar as hipóteses propostas e, conseqüentemente, podem responder afirmativamente à questão norteadora da pesquisa. Porém, nossas conclusões levam-nos, também, a questionar até que ponto o turismo pode ser favorável ao estudo da ufologia, pois sendo ele um fenômeno capitalista, onde muitas vezes (para não falar sempre) o lucro é prioridade, faz com que todos que trabalham com o turismo reflitam para que as pesquisas ufológicas não caiam na banalização e não comprometam anos de pesquisa sérias e importantes para o meio científico.

Conforme salientado anteriormente, a intercessão entre as variáveis ufologia e turismo, tema desta monografia, se dá de forma privilegiada, pois ambas possuem este aspecto multi, pluri, inter e transdiciplinar. O turismo, além de abarcar a ufologia, e, conseqüentemente, descobrir e lucrar com novos nichos de mercado está, também, em busca de alternativas frente à crise de paradigma mecanicista e fragmentado do nosso atual sistema. (Siqueira, 2005).

Destacamos a iniciativa desta monografia de propor um conceito do que seria o ufo turismo, uma vez que alguns web sites utilizam este termo, mas não há, ainda, entre os livros acadêmicos ou mesmo entre os turismólogos uma definição do que seriam estes.

Salientamos, ainda, a necessidade de destacarmos que o ufo turismo quase sempre está associado ao ecoturismo e ao turismo místico, uma vez que visam o desenvolvimento sustentável nestas regiões.

Por fim, passando ao longo da ciência e desafiando seus métodos e conceitos, o fenômeno óvni desencadeia profundas indagações a respeito da origem e da finalidade da vida, obrigando a mergulhos profundos, indagações 
estas para as quais a grande maioria das pessoas na atualidade parece não estar disposta. 


\section{Referências Bibliográficas}

AURÉLIO, Buarque de Holanda Ferreira. Novo dicionário da língua portuguesa. 2. ed. Rio de Janeiro: Nova Fronteira, 1986. 1838 p.

BARRETO, Margarita. Manual de iniciação ao estudo do turismo. 8. ed. Campinas: Papirus, 1995. 164 p.

BENI, Mário Carlos. Análise estrutural do turismo. 6. ed. São Paulo: Senac, 2001. 427 p.

BÍBLIA. Português. Bíblia Sagrada. Tradução de João Ferreira de Almeida. São Paulo: Casa Publicadora Brasileira, 1993. 307p.

BUTTLAR, Johannes Von. Fenômeno ufo: Provas de contatos imediatos do primeiro, segundo e terceiro graus. São Paulo: Melhoramentos, 1980. 151p.

DIAS, Reinaldo; AGUIAR, Marina Rodrigues. Fundamentos do turismo: conceitos, normas e definições. Campinas: Alínea, 2002. 287 p.

ERA DE PAZ. Era de paz. Disponível em: <http://www.eradepaz.com.br> Acesso em: 21 de dezembro 2004.

FENÔMENO MATRIX. Fenômeno Matrix. Disponível em: $<$ http//www.fenômeno.matrix> Acesso em 27 de dezembro 2000.

GEPUC. Gepuc. Disponível em: <http//www.gepuc.cjb.net. Acesso em: 11 de agosto de 2005.

GUIA QUATRO RODAS. São Paulo: Abril, 2003. Anual. ISSN: 01045059

IGNARRA, Luiz Renato. Fundamentos do turismo. São Paulo: Pioneira, 2001. 195 p.

INFA. Infa. Disponível em: <http//www.infa.com.br> Acesso em 05 de maio de 2005.

IUFOMURC. Disponível em: <http://iufomrc.com/about.shtml> Acesso em 20 de outubro de 1996.

MAUSO, Pablo Villarubia. Mistérios do Brasil: 20.000 quilômetros através de uma geografia oculta. São Paulo: Mercuryo, 1997. 319 p.

MICHAELIS, Henriette. Moderno dicionário da língua portuguesa. 2. ed. São Paulo: Melhoramentos, 1993-1998. 2267 p.

MISTÉRIOS DO DESCONHECIDO. Contatos alienígenas. São Paulo: Abril, 1993-1996. Mensal. 
Lugares místicos. São Paulo: Abril, 1993-1996. Mensal.

O fenômeno óvni. São Paulo: Abril, 1993-1996. Mensal.

NETO, José Fonseca Ferreira. Ciência dos mitos e o mito da ciência. 1984. 165 f. Dissertação (Mestrado em Antropologia) - Faculdade de Ciências Humanas, Universidade de Brasília, 1984.

REVISTA GALILEU. Revista Galileu. Disponível em: $<$ http//www.revistagalileu.globo.com>. Acesso em 17 de novembro de 2004.

ROMERO, Alberto. Verdades que incomodam. Salvador: Centro brasileiro de pesquisas de discos voadores, 1999. $445 \mathrm{p}$.

RUSSO, Sérgio. Nas fronteiras do desconhecido. Rio de Janeiro: Tecnoprint, 1985. $256 \mathrm{p}$.

SC. Portal Turismo de Santa Catarina. Disponível em: <http.www.sc.gov.br/portalturismo> Acesso em 12 de maio 2005.

SIQUEIRA, Deis Elucy. As novas religiosidades no ocidente: Brasília, cidade mística. Brasília: Universidade de Brasília, 2003. 129 p.

História social do turismo. Rio de Janeiro: Vieira, 2005. 163 p.

SOCEX. Socex. Disponível em: <http//www.socex.net. Acesso em: 22 de dezembro 2004.

THOMPSON, Richard. Identidades alienígenas: O fenômeno ufológico moderno sob a crítica da sabedoria antiga. Rio de Janeiro: Nova era, 2002. 254 p.

UCHOA, Alfredo Moacir de Mendonça. Mergulho no hiperespaço: Dimensões esotéricas na pesquisa dos discos voadores. 2 . ed. Brasília: Horizonte, 1979. 160 p.

UFO. Centro brasileiro de discos voadores. Disponível em: $<$ http//www.ufo.com.br>. Acesso em 04 de fevereiro 2005.

UFOGENESIS. Ufo Gênesis. Disponível em: $<$ http//www.ufogenesis.com.br>. Acesso em 11 de maio 2005.

VIAFANZINE. Via Fanzine. Disponível em: <http//www.viafanzine.yan.com.br> Acesso em 08 de maio 2005.

VIGÍLIA. Vigília. Disponível em: <http//www.vigilia.com.br> Acesso em 18 de novembro 2004. 